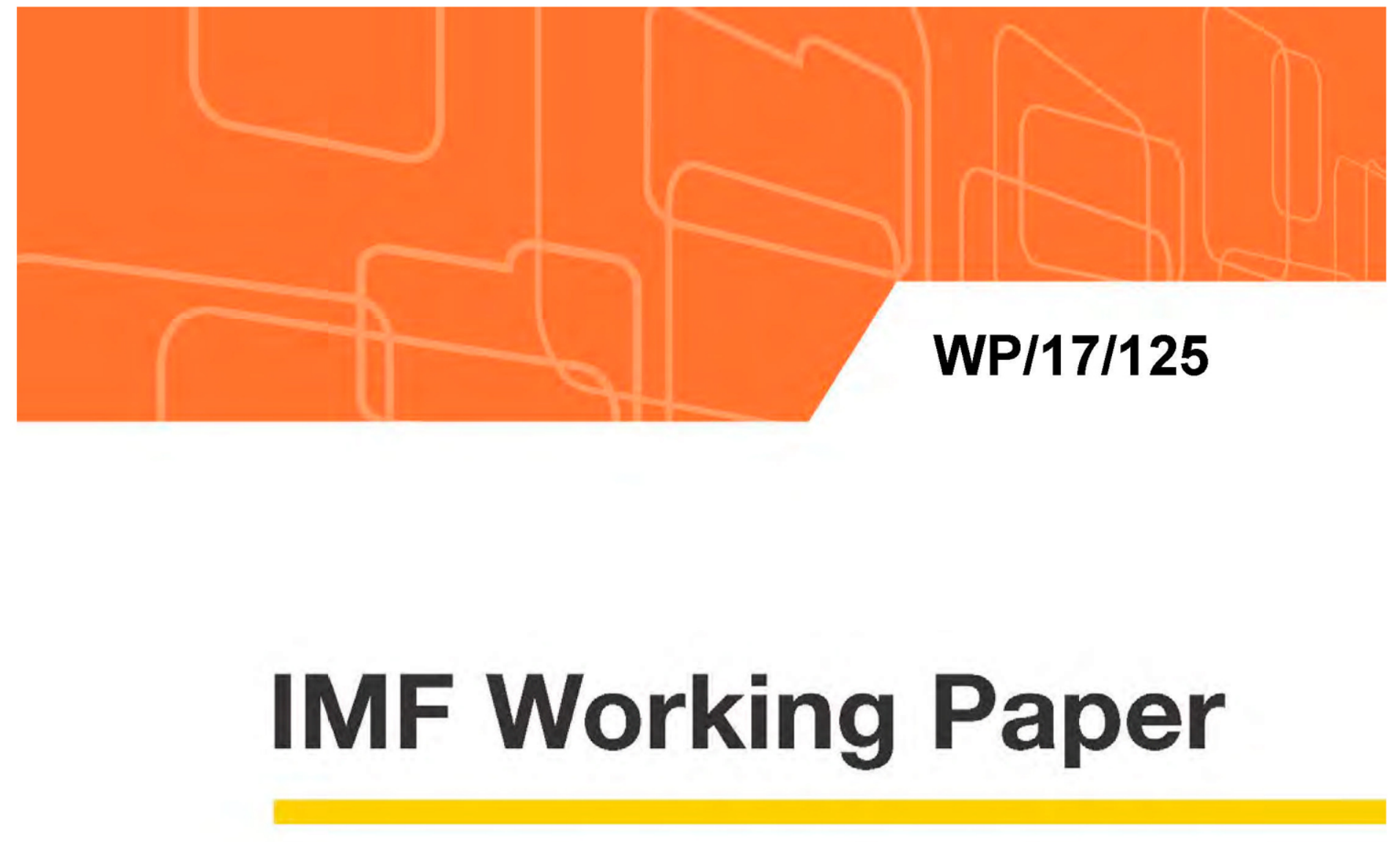

\title{
Structural Reform Packages, Sequencing, and the Informal Economy
}

by Zsuzsa Munkacsi and Magnus Saxegaard

IMF Working Papers describe research in progress by the author(s) and are published to elicit comments and to encourage debate. The views expressed in IMF Working Papers are those of the author(s) and do not necessarily represent the views of the IMF, its Executive Board, or IMF management. 


\section{WP/17/125}

\section{IMF Working Paper}

\section{Structural Reform Packages, Sequencing, and the Informal Economy}

by Zsuzsa Munkacsi and Magnus Saxegaard

IMF Working Papers describe research in progress by the author(s) and are published to elicit comments and to encourage debate. The views expressed in IMF Working Papers are those of the author(s) and do not necessarily represent the views of the IMF, its Executive Board, or IMF management.
I N T E R
N A T I O N A L
$M O N E T A R Y$
F U N D 


\title{
IMF Working Paper
}

Strategy, Policy, and Review Department

\section{Structural Reform Packages, Sequencing, and the Informal Economy \\ Prepared by Zsuzsa Munkacsi and Magnus Saxegaard}

Authorized for distribution by Mary Goodman

May 2017

\section{IMF Working Papers describe research in progress by the author(s) and are published to elicit comments and to encourage debate. The views expressed in IMF Working Papers are those of the author(s) and do not necessarily represent the views of the IMF, its Executive Board, or IMF management.}

\begin{abstract}
This paper explores the macroeconomic impacts of labor and product market deregulation using a small open-economy model with formal and informal markets. We examine both the long-run effects and the transition towards the post-reform equilibrium, while our main focus are reform packages and sequencing. The unofficial sector is a major determinant of the sign, and, in particular, the magnitude of responses. South Africa, an emerging country, is considered when Bayesian estimating the model. Regarding the long run, both labor and product market reforms considerably increase output, although labor market reforms are more successful in decreasing unemployment. Nevertheless, there are short-term costs, for example, a decrease in household consumption, net exports or output, or a decrease in competition. Combining reforms, especially with product market deregulation, are good at reducing short-term costs. Finally, concerning the speed of adjustment, it is usually better to start with a labor market reform.
\end{abstract}

JEL Classification Numbers: E6, E26, J08, J46

Keywords: structural reforms, labor market deregulation, product market deregulation, unemployment, hiring costs, endogenous firm entry, shadow economy, informal employment, small-open economy, reform packages, sequencing

Author's E-Mail Address: ZMunkacsi@imf.org (primary contact), MSaxegaard@imf.org. 


\section{Motivation and literature}

Lackluster growth in the aftermath of the global financial crisis coupled with limited scope for further macroeconomic stimulus has renewed interest in the impact of growth-enhancing structural reforms. For example, the President of the European Central Bank (Mario Draghi) recently noted that, in addition to monetary policy, "structural reforms are key" for achieving prosperity.

${ }^{1}$ At the same time, IMF (2014) also argues that product and labor market deregulation (promotion of competition, relaxation of hiring and firing regulations) can yield a sizeable growth dividend.

Important contributions to the literature on structural reforms include Blanchard and Giavazzi (2003), Kugler and Pica (2004), Berger and Danninger (2005), Boken and Hallett (2008), Fernandez-Villaverde et al. (2014) and Cacciatore and Fiori (2016), among others. ${ }^{2}$

Acknowledging that product and labor market regulation are an integral part of a country's competitiveness, several authors extend the analysis to an open-economy setting. Recent examples include Lusinyan and Muir (2013), Andres et al. (2014), Vogel (2014), Eggertson et al. (2014), or Cacciatore et al. (2016b).

Additionally, there is a lot of attention on tax evasion. The last " $T$ " in the "three Ts" that were discussed by the Group of Eight at their summit in 2013 was tax ${ }^{3}$ in particular, they emphasized the importance of fighting tax evasion. Also, G20 leaders in November 2015 endorsed some steps in order to crack down on evasion of taxes. ${ }^{4}$

Tax evasion is the major part of shadow economy ${ }^{5}$, in company with avoiding regulations. Notably, as Schneider et al. (2010) points out, shadow economy is mostly related to taxation or legal requirements in general. ${ }^{6}$ We are aware of only one paper, Charlot et al. (2015), however, which looks at the macroeconomic effects of labor and product market reforms in the presence of informality, and, to the best of our knowledge there are no papers which combine informality with openness. ${ }^{7}$ Nevertheless, there are several reasons to believe that the informal sector, and its interaction with openness, must be considered when studying the macroeconomic impacts of structural reforms.

\footnotetext{
${ }^{1}$ Monetary Policy and Structural Reforms in the Euro Area

${ }^{2}$ Papers which consider either product or labor market deregulation include Nicoletti and Scarpetta (2003), Besley and Burgess (2004), Conway et al. (2005), and Ebell and Haefke (2009), for instance. Alesina et al. (2005) or Estevao (2005) mainly investigate other than growth (investment, wage) impacts of reforms. Gali (2011) study the impact of fiscal consolidation and an increase in competition on productivity. Also, Cacciatore et al. (2016c) examine optimal monetary policy in a monetary union in the presence of product and labor market regulation. In addition, Gomes et al. (2013) explore the effects of increasing competition in the labor and services markets. Finally, Gnocchi et al. (2015) find that labor market reforms influence business cycles, while Cacciatore et al (2016b) focus on the role of business cycle conditions when studying the consequences of product and labor market reforms. As well, we would like to note that in this paper we do not review empirical literature on labor and/or product market regulations in detail.

${ }^{3}$ E.g. The Economist published an article on 22 June 2013 with the title of The G8 summit: T time.

${ }^{4}$ See a note on OECD's contribution for instance.

${ }^{5}$ In our paper the terms shadow, informal, underground and unofficial are interchangeable.

${ }^{6}$ See Appendix A for precise definitions.

${ }^{7}$ When studying public policies in general, shadow economy is not rarely ignored. Exceptions are Batini et al. (2011) who explore optimal monetary policy taking a shadow sector into account, or Ihrig and Moe (2004) on the impacts of taxation on the shadow economy. As well, Pappa et al. (2015) revisit fiscal multipliers in the presence of tax evasion and corruption.
} 
The informal sector is, by definition, beyond government's reach, and will therefore not be directly affected by product or labor market deregulation, or indeed by any other government policies like taxation. Thus, the larger the unofficial sector, the smaller the fraction of the economy directly impacted by government actions. In the absence of any linkages between the formal and informal sectors, the overall macroeconomic effects of labor and product market deregulation would therefore always increase with the relative size of the formal sector ("composition effect"). However, there are important linkages between the formal and informal sectors, and product and labor market deregulation are therefore likely to have significant feedback effects ("substitution effect"). Deregulation may reduce incentives for firms and workers to operate in the informal sector, and thus increase the relative size of the formal sector. There is also a productivity differential between the two sectors which can magnify the impact of structural reforms (Farrell, 2004; Bailey et al., 2005; or La Porta and Shleifer, 2008). On the other hand, some authors (e.g. Boeri and Garibaldi (2007)) argue that the informal economy acts as a shock absorber, so, it reduces the overall impact of adverse macroeconomic shocks on unemployment. A version of our model calibrated to an emerging market economy confirms that the informal sector has a major impact on the sign, and magnitude of macroeconomic effects of structural reforms.

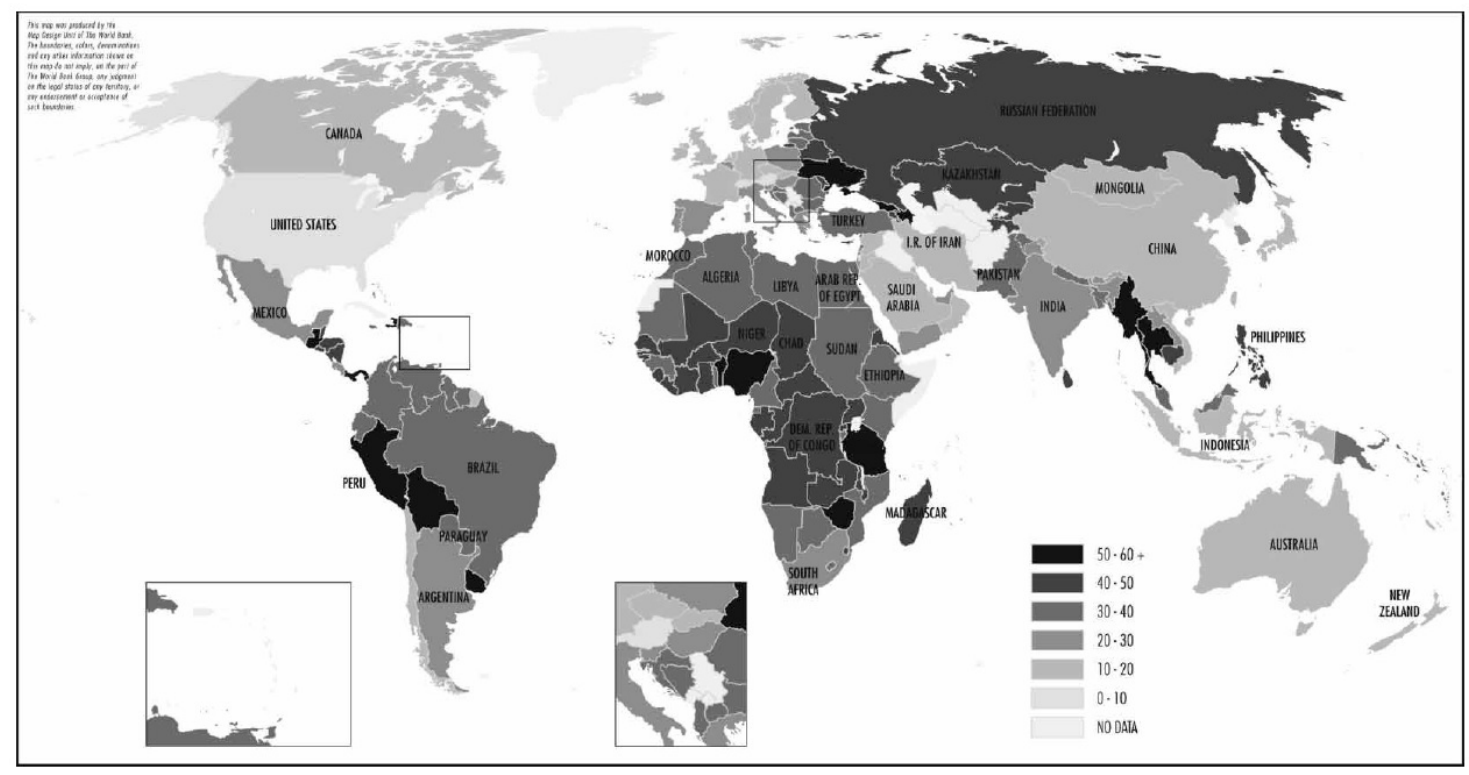

Figure 1: The fraction of shadow output in total output around the world. Source is Schneider et al. (2010, page 458).

Though difficult to estimate precisely, what evidence exists suggests that the informal sector in many countries is sizeable, and it is more significant in emerging or low-income countries than in advanced economies (Figure 1). For instance, Schneider (2005) estimates that 16 percent of OECD countries' GDP and 41 percent of African countries' GDP is informal. The share of employment in the informal sector might be even higher (60.5 percent in Africa), suggesting that firms operating in the informal sector are concentrated in relatively laborintensive industries (Schneider, 2012). The very size of the informal economy in several countries also suggests that it could have important implications for the impacts of structural reforms.

This paper revisits the macroeconomic impacts of product and labor market reforms in an open-economy dynamic general equilibrium framework with formal and informal sectors. In 
addition to the long-run effects, we examine the path to the new post-reform equilibrium to gauge the size of any short-run costs associated with the reforms. While doing so, we mainly concentrate on joint reforms and sequencing.

Our paper is closely related to the study by Charlot et al. (2015). We expand on their analysis, however, by (i) looking at the impacts of product and labor reforms in an openeconomy setting; (ii) explicitly modeling the short-run as a transition to the post-reform equilibrium (rather than treating short- and long-run independently); (iii) elaborating on the importance of interactions between different reforms and sequencing; and (iv) also slightly broadening the characterization of the informal sector. ${ }^{8}$ Our study is also strongly linked to Cacciatore et al. (2016b) and IMF (2015b) who examine the short- and long-run impacts of several product and labor reforms, also including joint reforms. They do that in an openeconomy model, nevertheless, (i) we also incorporate a shadow sector in the framework, and (ii) study sequencing of policies. Regarding sequencing, Khera and Tulin (2017) in a forthcoming work also explore labor and product market policies in India. ${ }^{9}$

The structural reforms we consider are permanent and unexpected reductions in the level of product and labor market regulations in the formal sector. Specifically, we assess the impacts of a decrease in the cost of hiring, a reduction in the bargaining power of workers, and a fall in firms' cost of entering the market. Examples of hiring costs include training or administrative costs. The bargaining power of workers, a form of employment protection, is mainly related to the level of unionization. Examples of entry costs include the cost and time involved in registering a new business. Papers without a shadow economy consider similar deregulation policies, however, not in the formal sector, but in the economy as a whole.

To illustrate our findings, we estimate the model, using Bayesian estimation techniques, on South Africa, a country with a relatively small informal sector compared to other emerging countries $^{10}$, and where structural reforms are at the forefront of policy debate. ${ }^{11}$ Also, unemployment in South Africa is large and persistent. This is true in spite of the fact that the labor market is relatively less regulated in a cross-country comparison (Figure 2).

Nevertheless, South African goods markets are among the most regulated in the world (Figure 3). A companion paper by Anand and Khera (2016) uses a similar model to ours to study India, where the size of the informal sector is very high.

Our results suggest that, in the long run, both labor and product market reforms imply a significantly positive impact on South African output. Nevertheless, labor market reforms are somewhat more successful than product market reforms at reducing unemployment.

Structural reforms reduce informality by increasing employment in the formal sector, but have little impact on the absolute level of employment in the informal sector. Short-run costs in the transition are non-trivial, and include a decline in consumption, exports or output, a reduction in wages, or lower competition. Combining reforms, especially with product market deregulation, are good at reducing short-term costs. Finally, concerning the speed of adjustment, it is usually better to start with a labor market reform.

\footnotetext{
${ }^{8}$ Informality in Charlot et al. (2015) is defined as tax evasion and lower level of regulation.

${ }^{9}$ In addition, Asturiasa et al. (2016) examine sequencing of trade and product market policies. Also, Kugler and Pica (2004) find that entry barriers in the product markets mitigate the impact of labor market deregulation.

${ }^{10}$ The share of informal GDP in total GDP in South Africa is 28.4 in Schneider (2005), and 24 percent in IMF (2017). The share of informal employment in total employment varies between 15.8 and 34.6 percent (Table 3), also, the number of informally employed people increased by 400 thousand since 2010 (SSA, 2017).

${ }^{11}$ See e.g. IMF (2014) or IMF (2016).
} 


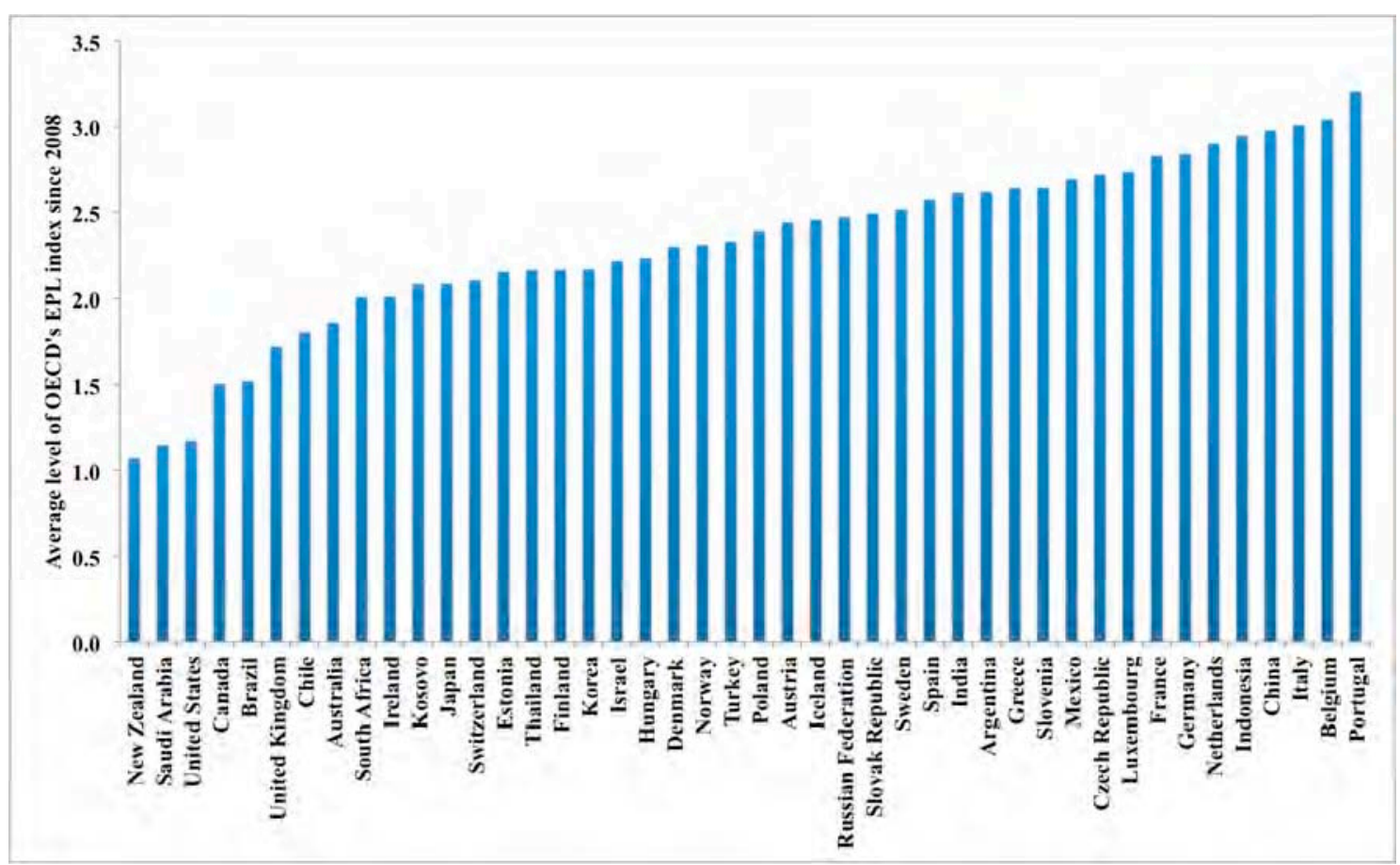

Figure 2: Level of labor market deregulation. The EPL index shows the strictness of employment protection (individual and collective dismissals of regular contracts) published by the OECD.

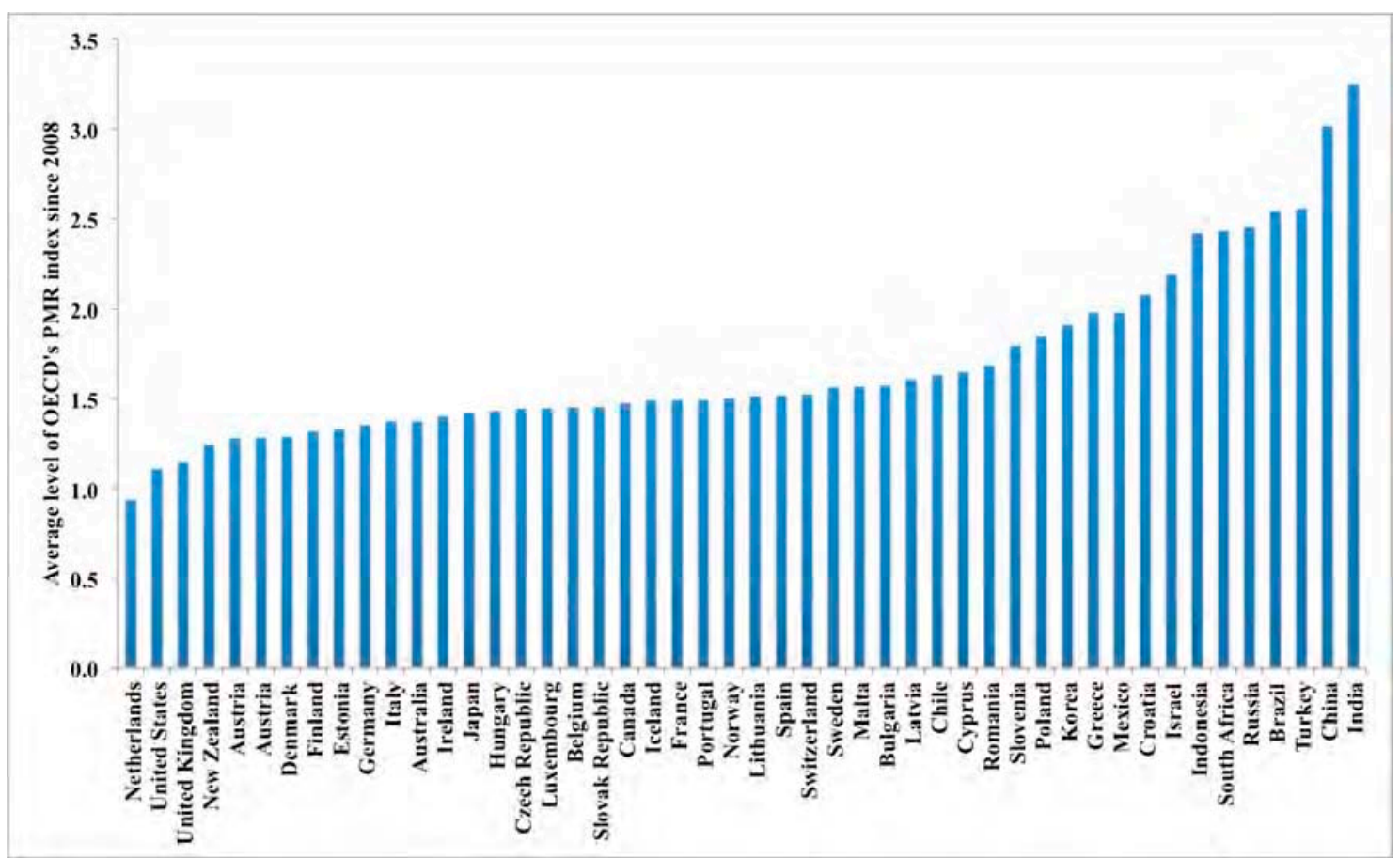

Figure 3: Level of product market deregulation. The OECD's Product Market Regulation indicator measures the degree to which policies promote or inhibit competition in areas of the product market where competition is viable. 
The rest of the paper is organized as follows. We describe the model in detail before discussing calibration and estimation. We then analyze a number of policy experiments that assess the long- and short-term impacts of individual reforms, reform packages, as well as sequencing; with a focus on the latter two. We conclude with a brief summary of our findings.

\section{The model}

The model is a small open-economy dynamic general equilibrium model with unemployment due to hiring costs and wage bargaining following Blanchard and Gali (2010), and endogenous firm entry like Bilbie et al. (2012). Figure 4 shows an overview of its structure. ${ }^{12}$ The main novelty is the distinction between formal and informal sectors in the labor and goods markets. On the one hand, it means tax evasion in the underground economy, on the other hand, in line with Williamson (1975), the level of regulation is lower in the informal sector. Also, openness is only a consideration in the formal sector.

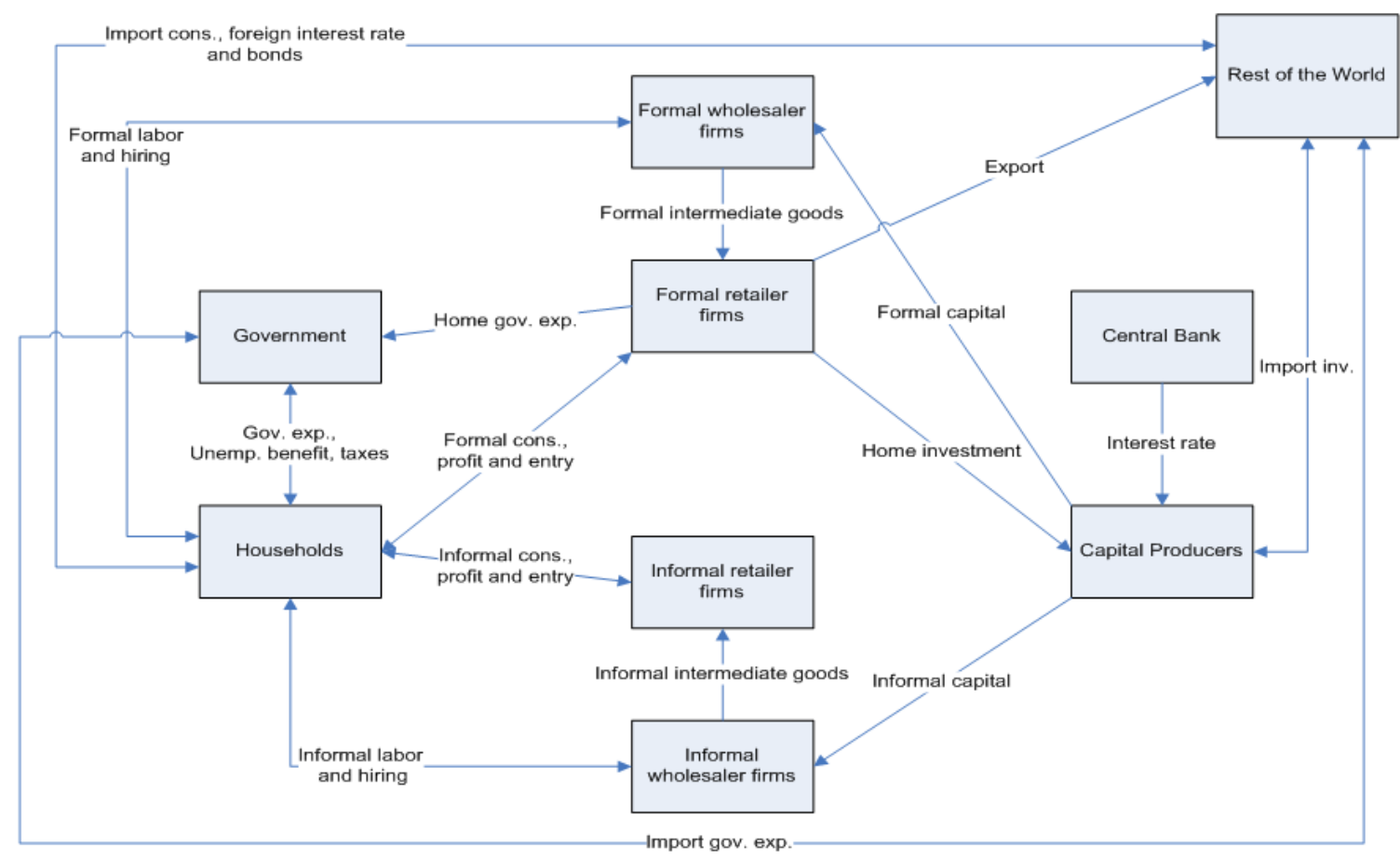

Figure 4: The structure of the model

The household sector is standard; there is a representative infinitively living household that maximizes the expected discounted lifetime utility of consumption. However, consumption is an aggregate of home and foreign produced goods, while home produced goods are an aggregate of goods produced in the formal and informal sectors. Then, as regards the budget constraint, labor income originates from both the official and unofficial economies; while the former is taxed. Also, the household owns all the firms,

\footnotetext{
${ }^{12}$ Notation is as follows: $\mathrm{F}$ for formal, $\mathrm{I}$ for informal, $\mathrm{H}$ for home, $\mathrm{f}$ for foreign (import), $\mathrm{W}$ for wholesaler (intermediate), and $\mathrm{R}$ for retailer (final).
} 
and so finances new firms' entry cost, in both sectors, which is equal to the expected discounted future profit-stream of firms.

Both formal and informal wholesale good producers produce an intermediate good by a Cobb-Douglas production function. Both pay not only the cost of labor and capital as usual, but additionally a hiring cost of newly hired workers, while labor follows a law of motion similarly to that of capital. Next, as regards retailers, due to endogenous entry, their number is not normalized to one, but is related to the law of motion of the number of firms. Additionally, the number of firms, in both the official and unofficial sectors, endogenously affect price markups.

Now, turning our attention to regulation, i.e. rigidities related to hiring, bargaining and entry, the crucial point is that they are lower in the shadow. On the one hand, formal-sector firms incur greater hiring costs than do firms in the informal sector. These costs can be associated with training to make up for educational or experiential deficits on the worker's part, but they might reflect as well administrative costs such as the time spent on hiring. Then too, the bargaining power of workers in wage setting is higher in the formal than in the informal sector. The strength of unions in the formal sector might be at play here, but this relative bargaining clout can also be related to the sector's legal environment, which provides more rights for workers than firms in setting wages. Employment protection might also be reflected in the fact that the probability of firing is relatively lower in the formal sector. Furthermore, registering a new company is costly, in terms of both money and time; formal entry costs are larger than informal ones. Finally, price mark-up is higher and firm exit rate, similarly to the dismissal rate of workers, is lower in the formal sector than in the underground economy.

Alongside differences in regulation levels, other features serve to distinguish the two sectors. Notably, only formal sector's labor income falls under the taxation umbrella. Also, by virtue of administrative regulations in the formal sector and lack of financing in the informal sector, the government can only purchase formal goods and investment is also a function of formal goods only. As well, labor productivity in the informal sector is lower than in the formal sector. Finally, formal goods are traded abroad, but informal goods are not, which is likely to be explained by the fact that entering the foreign markets requires meeting certain legal obligations. The fact that only formal goods are traded abroad constitutes the main example in our model of interactions between the shadow economy and openness.

At this point, we start to describe the model in detail, which is called STRESS that stands for Structural Reforms and Shadow Sector. It also reflects the need for (stress of) structural reforms that each country faces today, especially in the presence of a (large) shadow economy. Please note that whenever the formal maximization is parallel to the informal one, we only detail the former.

\subsection{Representative household}

There is a representative infinitely living household with perfect foresight that maximizes expected discounted lifetime utility of consumption $C_{t}$ :

$$
\max E_{0} \sum_{t=0}^{\infty} \beta^{t} \zeta_{C, t} U\left[C_{t}\right]
$$


The contemporaneous utility is given by $U\left[C_{t}\right]=(1-h c) \ln \left(C_{t}-C_{t-1}\right)$, where $\beta$ is the discount factor, $\zeta_{C, t}$ is the preference shock and $h c \in(0,1)$ is the external consumption habit parameter. This functional form ensures that habit persistence does not affect the long-run equilibrium.

The household faces a budget constraint in every period:

$$
\begin{aligned}
& C_{t}+R E R_{t} B_{t}+D_{t}+N_{F, t}^{E} \text { entry }_{F, t}+N_{I, t}^{E} \text { entry }_{I, t}+\operatorname{Tax}_{t}= \\
& =\operatorname{DEP} P_{t} \frac{1+i_{t-1}^{\star}}{\pi_{t}} R E R_{t-1} B_{t-1}+\frac{1+i_{t-1}}{\pi_{t}} D_{t-1}+N_{F, t} \operatorname{Prof}_{F, t}^{R}+N_{I, t} \operatorname{Prof}_{I, t}^{R}+ \\
& +\operatorname{Prof}_{F, t}^{W}+\operatorname{Prof}_{I, t}^{W}+\left(1-\tau_{F, t}\right) W F_{t} L_{F, t}+W I_{t} L_{I, t}+W U_{t} U_{t}+Y_{H P, t}
\end{aligned}
$$

As usual, the household consumes an aggregate consumption bundle $C_{t}$ and saves. Savings can be in the form of foreign bonds $B_{t}$ or in home bonds $D_{t}$; all markets are complete. $R E R_{t}$ is the real exchange rate and $D E P_{t}$ is the depreciation rate of the nominal exchange rate. Nominal interest rate on home bonds $i_{t}$ is determined by the central banks' Taylor rule, while nominal interest rate on foreign bonds $i_{t}^{\star}$ depends on the exogenous foreign interest rate, on the one hand, and on an interest rate premium related to the relative amount of foreign debt holdings, on the other hand, following Schmitt-Grohe and Uribe (2003).

The household owns wholesaler and retailer firms, denoted by $\mathrm{W}$ and $\mathrm{R}$, respectively, so the firms' respective profits return to the household. Because the retailer profit means one firm's profit, it is multiplied by the number of retailer firms. At the same time, there is no endogenous entry at the wholesaler level, or, to put it another way, the number of wholesaler firms is normalized to one. Endogenous firm entry at the retailer level also explains why the household finances entry costs $\left(e n t r y_{F, t}\right.$ and entry $\left.y_{I, t}\right)$ of new firms $N_{F, t}^{E}$ and $N_{I, t}^{E}$. Firm exit is exogenous with sectoral bankruptcy rates $\delta_{F}$ and $\delta_{I}$. Thus, the laws of motion for the number of retailer firms are:

$$
\begin{aligned}
& N_{F, t}=\left(1-\delta_{F, t}\right)\left(N_{F, t-1}+N_{F, t}^{E}\right) \\
& N_{I, t}=\left(1-\delta_{I, t}\right)\left(N_{I, t-1}+N_{I, t}^{E}\right)
\end{aligned}
$$

Here, we assume that a firm, which enters in period t, starts to operate in period t.

Besides profit, the household earns labor income from working in the formal sector $\left(L_{F, t}\right)$ or in the informal sector $\left(L_{I, t}\right)$, or it receives social benefits $W U_{t}$, which is an exogenous shock, if it is unemployed. $W F_{t}$ and $W I_{t}$ are the sectoral real wages;

although only the formal sector's wage is subject to income $\tau_{F, t}$ which is an exogenous variable. The household also pays a lump-sum tax $\operatorname{Tax}_{t}$ to close the model. Finally, $Y_{H P, t}$ denotes home production.

Given the utility function and the budget constraint, two Euler equations follow, one for each bond holdings:

$$
\begin{aligned}
& \beta\left(C_{t}-h c C_{t-1}\right) E_{t}\left[\frac{\left(1+i_{t}\right) \zeta_{C, t+1}}{C_{t+1}-h c C_{t}}\right]=E_{t}\left[\pi_{t+1} \zeta_{C, t}\right] \\
& \beta\left(C_{t}-h c C_{t-1}\right) E_{t}\left[\frac{\left(1+i_{t}^{\star}\right) \zeta_{C, t+1}}{C_{t+1}-h c C_{t}} D E P_{t+1}\right]=E_{t}\left[\pi_{t+1} \zeta_{C, t}\right]
\end{aligned}
$$


In the second Euler equation, which refers to foreign savings, the depreciation rate of the nominal exchange rate is also taken into account.

The aggregate consumption bundle $C_{t}$ consists of home-produced goods $C_{H, t}$ and foreign-produced (imported) goods $C_{f, t}$, and is given by:

$$
C_{t}=\left[\alpha^{\frac{1}{\eta}} C_{H, t}^{\frac{\eta-1}{\eta}}+(1-\alpha)^{\frac{1}{\eta}} C_{f, t}^{\frac{\eta-1}{\eta}}\right]^{\frac{\eta}{\eta-1}}
$$

where $\alpha \in(0,1)$ can be interpreted as a measure of home bias, or one could think of $1-\alpha$ as the import ratio which captures the degree of openness. $\eta>0$ is the elasticity of substitution between home and foreign produced goods.

Total cost spent on home- and foreign-produced goods is minimised. As a result, the demand functions and the aggregate price level $P_{t}$ - a composite of home price $P_{H, t}$ and foreign (import) price $P_{f, t}$ - are:

$$
\begin{aligned}
& C_{H, t}=\alpha C_{t}\left(\frac{P_{H, t}}{P_{t}}\right)^{-\eta} \\
& C_{f, t}=(1-\alpha) C_{t}\left(\frac{P_{f, t}}{P_{t}}\right)^{-\eta} \\
& P_{t}=\left[\alpha P_{H, t}^{1-\eta}+(1-\alpha) P_{f, t}^{1-\eta}\right]^{\frac{1}{1-\eta}}
\end{aligned}
$$

The relevant inflation rates are defined as follow:

$$
\begin{aligned}
& \pi_{t}=\frac{P_{t}}{P_{t-1}} \\
& \pi_{H, t}=\frac{P_{H, t}}{P_{H, t-1}} \\
& \pi_{f, t}=\frac{P_{f, t}}{P_{f, t-1}}
\end{aligned}
$$

Similarly to aggregate consumption, home consumption $C_{H, t}$ is also a composite, namely, it is a composite of goods produced in the formal sector $C_{F, t}$ and goods produced in the informal sector $C_{I, t}$ :

$$
C_{H, t}=\left[\omega^{\frac{1}{\mu}} C_{F, t}^{\frac{\mu-1}{\mu}}+(1-\omega)^{\frac{1}{\mu}} C_{I, t}^{\frac{\mu-1}{\mu}}\right]^{\frac{\mu}{\mu-1}}
$$

where $\omega \in(0,1)$ represents the weight of formal sector goods in the basket, and $\mu>0$ is the elasticity of substitution between sectoral goods.

Total cost spent on formal and informal goods is minimised, which implies the demand functions:

$$
\begin{aligned}
& C_{F, t}=\omega C_{H, t}\left(\frac{P_{F, t}}{P_{H, t}}\right)^{-\mu} \\
& C_{I, t}=(1-\omega) C_{H, t}\left(\frac{P_{I, t}}{P_{H, t}}\right)^{-\mu}
\end{aligned}
$$


Also, as a result of optimization, we can specify the price of home goods $P_{H, t}$ as a function of $P_{F, t}$ formal and $P_{I, t}$ informal price levels:

$$
P_{H, t}=\left[\omega P_{F, t}^{1-\mu}+(1-\omega) P_{I, t}^{1-\mu}\right]^{\frac{1}{1-\mu}}
$$

Relevant inflation rates are:

$$
\begin{aligned}
\pi_{F, t} & =\frac{P_{F, t}}{P_{F, t-1}} \\
\pi_{I, t} & =\frac{P_{I, t}}{P_{I, t-1}}
\end{aligned}
$$

\subsection{Capital producer}

The capital producer owns physical capital, and, by investing, produces new physical capital. Investment is subject to a capital adjustment cost. This set-up follows that of Bernanke et al. (1999).

The capital law of motion is standard, except that the price of investment is not equal to the general economy-wide price level:

$$
K_{t}=(1-\delta) K_{t-1}+\frac{P_{I N V, t}}{P_{t}} I_{t}-\frac{\phi_{I N V}}{2}\left(\frac{\frac{P_{I N V, t}}{P_{t}} I_{t}}{K_{t-1}}-\delta\right)^{2} K_{t-1}
$$

This is because only goods produced in the formal sector can be used for investment, by assumption. The $\frac{\phi_{I N V}}{2}\left(\frac{\frac{P_{I N V, t}}{P_{t}} I_{t}}{K_{t-1}}-\delta\right)^{2} K_{t-1}$ capital adjustment cost is zero in the long run, but varies around the steady state, with $\phi_{I N V}$ being the capital adjustment cost parameter and $\delta$ the depreciation rate of physical capital.

The capital producer invests such that its profit is maximized:

$$
\max Q_{t}\left\{\frac{P_{I N V, t}}{P_{t}} I_{t}-\frac{\phi_{I N V}}{2}\left(\frac{\frac{P_{I N V, t}}{P_{t}} I_{t}}{K_{t-1}}-\delta\right)^{2} K_{t-1}-\frac{P_{I N V, t}}{P_{t}} I_{t}\right\}
$$

where $Q_{t}$ is the price of physical capital.

As a result, the Tobin-Q equation follows:

$$
Q_{t}\left(1-\phi_{I N V}\left(\frac{\frac{P_{I N V, t}}{P_{t}} I_{t}}{K_{t-1}}-\delta\right)\right)=1
$$

Also, because no arbitrage is possible, the following condition holds:

$$
E_{t} \frac{1+i_{t}}{\pi_{t+1}}=E_{t} \frac{R K_{t+1}+(1-\delta) Q_{t+1}}{Q_{t}}
$$

This condition means that the real return on saving in home bonds must equal the net return on saving in physical capital, which is the ratio of the sum of the current period's 
physical capital price level and real rental rate of capital $R K_{t}$ and previous period's physical capital price level.

Finally, aggregate investment, like aggregate consumption, is a composite good.

Notably, it is a composite of home produced and imported goods:

$$
I_{t}=\left[\alpha^{\frac{1}{\eta}} I_{H, t}^{\frac{\eta-1}{\eta}}+(1-\alpha)^{\frac{1}{\eta}} I_{f, t}^{\frac{\eta-1}{\eta}}\right]^{\frac{\eta}{\eta-1}}
$$

where $\alpha \in(0,1)$ and $\eta>0$ represent the same parameters as before. Nevertheless, we would like to stress that home investment is a function of formal goods only, which explains the fact that the home demand function depends on the formal goods' price level and the price of investment does not depend on the informal goods' price level either:

$$
\begin{aligned}
& I_{H, t}=\alpha I_{t}\left(\frac{P_{F, t}}{P_{I N V, t}}\right)^{-\eta} \\
& I_{f, t}=(1-\alpha) I_{t}\left(\frac{P_{f, t}}{P_{I N V, t}}\right)^{-\eta} \\
& P_{I N V, t}=\left[\alpha P_{F, t}^{1-\eta}+(1-\alpha) P_{f, t}^{1-\eta}\right]^{\frac{1}{1-\eta}}
\end{aligned}
$$

A similar assumption is made regarding government consumption; thus, the price of investment is equal to the price of government consumption, and home demand for government consumption depends on the formal goods' price level only.

\subsection{Wholesale good producers}

A continuum of entrepreneurs of $(0,1)^{13}$ in each sector use labor $\left(L_{F, t}\right.$ or $\left.L_{I, t}\right)$ and physical capital $\left(K_{F, t}\right.$ or $\left.K_{I, t}\right)$ to produce intermediate goods $\left(Y_{F, t}\right.$ or $\left.Y_{I, t}\right)$, following a constant returns to scale technology:

$$
\begin{aligned}
& Y_{F, t}=\theta_{F, t}\left(K_{F, t-1}\right)^{\psi_{F}}\left(L_{F, t}\right)^{1-\psi_{F}} \\
& Y_{I, t}=\theta_{I, t}\left(K_{I, t-1}\right)^{\psi_{I}}\left(L_{I, t}\right)^{1-\psi_{I}}
\end{aligned}
$$

$\theta_{F, t}$ and $\theta_{I, t}$ are exogenous sectoral productivities, and $\psi_{F}$ and $\psi_{I}$ are the sectoral capital income shares.

From now on, we only describe the formal sector, as the informal sector's optimization is a mirror image of it. The one-period profit of the formal intermediate firm is equal to revenue net costs spent on labor and physical capital; the cost of hiring new workers is deducted, too:

$$
\operatorname{Prof}_{F, t}^{W}=M C_{F, t} Y_{F, t}-W F_{t} L_{F, t}-R K_{t} K_{F, t-1}-H C_{F, t} H_{F, t}
$$

$M C_{F, t}$ is the real marginal cost of production, which is equal to the price of intermediate goods as we assume that intermediate firms are price takers. The hiring cost is denoted by $H C_{F, t}$, while $H_{F, t}$ is the number of hired people.

\footnotetext{
${ }^{13}$ Because in equilibrium all $i \in(0,1)$ intermediate firms follow the same optimization process, for the sake of simplicity we disregard the symbol i when describing the intermediate firms' optimization in most of this section.
} 
The number of employed people follows a law of motion:

$$
L_{F, t}=\left(1-\operatorname{probf}_{F, t}\right) L_{F, t-1}+H_{F, t}
$$

At the beginning of period $t L_{F, t-1}$ people are employed. Then, at the beginning of period $t$ probf $f_{F, t} L_{F, t-1}$ people are fired, where the exogenous firing probability is $\operatorname{probf}_{F, t}$. During period $t$, firms hire new workers. After firing and hiring is over, the end of period $t$ employment will be $L_{F, t}$, which is also the level of employment at the beginning of period $t+1$.

Regarding labor market frictions, unemployment is induced by the above-noted hiring costs. The set-up of these labor market frictions closely follows that of Blanchard and Gali (2010). The hiring cost and the search and matching frictions differ mainly in that the hiring itself is costly. Thus, unemployment costs mostly reflect not the search itself or the possible inefficiency of the match, but rather the cost - above the wage - of hiring a new worker. This is the training cost: if the educational level or expertise of the worker does not meet the needs of the firm, it must train the worker. Alternatively, one could think of this hiring cost as a cost the firm pays to the government or another company (head-hunter, recruiter), or it can proxy the administration "costs" incurred by the firm when hiring (i.e. social security paperwork, etc.)

In our model, hiring cost is a function of hiring probability:

$$
H C_{F, t}=\beta_{H C F, t}\left(\operatorname{probh}_{F, t}\right)^{\alpha_{H C F}}
$$

where the hiring probability is:

$$
\operatorname{probh}_{F, t}=\frac{H_{F, t}}{U_{t-1}+\operatorname{probf}_{F, t} L_{F, t-1}+\operatorname{probf}_{I, t} L_{I, t-1}}
$$

Thus, the probability of hiring depends on the number of hired people $H_{F, t}$ (the higher the number of hired people, the higher the probability of hiring) and on the number of people - potentially - available to hire. We assume that not only those who were unemployed at the beginning of period $t$ can be hired, but also those who have just lost their jobs in any of the sectors. The exogenous term $\beta_{H C F, t}$ represents the per capita hiring cost, and this is the labor market deregulation variable, too. Finally, $\alpha_{H C F}$ is the elasticity of hiring cost with respect to the hiring probability.

Formal sector firms maximize the expected present value of future profits:

$$
\max E_{t} \sum_{j=0}^{\infty} Q_{t, t+j} \operatorname{Prof}_{F, t+j}^{W}
$$

subject to the employment law of motion discussed above. The discount rate is consistent with the Euler equation of the household $Q_{t, t+j}=\beta \frac{U_{c, t+j}}{U_{c, t}}$.

Capital and labor demand functions follow:

$$
M C_{F, t} \psi_{F} \frac{Y_{F, t}}{K_{F, t-1}}=R K_{t}
$$




$$
\begin{aligned}
& M C_{F, t}\left(1-\psi_{F}\right) \frac{Y_{F, t}}{L_{F, t}}-W F_{t}= \\
& =H C_{F, t}-\beta \frac{C_{t}-h c C_{t-1}}{\zeta_{C, t}} E_{t}\left[\frac{\zeta_{C, t+1}}{C_{t+1}-h c C_{t}}\left(1-\operatorname{probf}_{F, t+1}\right) H C_{F, t+1}\right]
\end{aligned}
$$

The capital demand function is standard. Nevertheless, the labor demand function becomes dynamic due to the presence of labor market frictions, that is, not only the wage is taken into account, but also the current and next period's hiring cost.

Wage setting is sectoral and follows a Nash bargaining process between workers and wholesaler firms, with exogenous sectoral bargaining power of the workers $\lambda_{F, t}$ and $\lambda_{I, t}$.

In period $t$ a worker is either employed in the formal sector, or she is employed in the informal sector, or she is unemployed. If a worker is employed in the formal sector, her current wage is $\left(1-\tau_{F, t}\right) W F_{t}$. In the next period, she might keep her job with probability $1-\operatorname{prob} f_{F, t+1}$, or she might be fired with probability $\operatorname{prob} f_{F, t+1}$. If she is fired, she might find another job either in the formal sector, with probability $\operatorname{prob}_{F, t+1} \operatorname{probh}_{F, t+1}$, or in the informal sector, with probability $\operatorname{prob}_{F, t+1} \operatorname{probh}_{I, t+1}$, or she might stay unemployed, with probability $\operatorname{prob}_{F, t+1}\left(1-\operatorname{probh}_{I, t+1}-\operatorname{probh}_{F, t+1}\right)$. Hence, the value function of being employed in the formal sector in period $t$ is:

$$
\begin{aligned}
& V_{t}^{F}=\left(1-\tau_{F, t}\right) W F_{t}+E_{t}\left\{Q_{t, t+1}\left[\left(1-\operatorname{probf}_{F, t+1}+\operatorname{probf}_{F, t+1} \operatorname{probh}_{F, t+1}\right) V_{t+1}^{F}\right]\right\}+ \\
& +E_{t}\left\{Q_{t, t+1}\left[\operatorname{probf}_{F, t+1} \operatorname{probh}_{I, t+1} V_{t+1}^{I}+\operatorname{probf}_{F, t+1}\left(1-\operatorname{probh}_{I, t+1}-\operatorname{probh}_{F, t+1}\right) V_{t+1}^{U}\right]\right\}
\end{aligned}
$$

The value function of being employed in the informal sector is similar, except that the worker does not pay labor income tax today:

$$
\begin{aligned}
& V_{t}^{I}=W I_{t}+E_{t}\left\{Q_{t, t+1}\left[\left(1-\operatorname{prob}_{I, t+1}+\operatorname{probf}_{I, t+1} \operatorname{probh}_{I, t+1}\right) V_{t+1}^{I}\right]\right\}+ \\
& +E_{t}\left\{Q_{t, t+1}\left[\operatorname{probf}_{I, t+1} \operatorname{probh}_{F, t+1} V_{t+1}^{F}+\operatorname{probf}_{I, t+1}\left(1-\operatorname{probh}_{I, t+1}-\operatorname{probh}_{F, t+1}\right) V_{t+1}^{U}\right]\right\}
\end{aligned}
$$

If a worker is currently unemployed, she receives social security benefits today, and in the next period she might be unemployed still, with probability $1-\operatorname{probh}_{I, t+1}-\operatorname{probh}_{F, t+1}$, or she might find a job in any of the two sectors:

$$
\begin{aligned}
& V_{t}^{U}=W U_{t}+ \\
& +E_{t}\left\{Q_{t, t+1}\left[\left(1-\operatorname{probh}_{I, t+1}-\operatorname{probh}_{F, t+1}\right) V_{t+1}^{U}+\operatorname{probh}_{F, t+1} V_{t+1}^{F}+\operatorname{probh}_{I, t+1} V_{t+1}^{I}\right]\right\}
\end{aligned}
$$

Workers' surplus of being employed in the formal or in the informal sector are $V_{t}^{F}-V_{t}^{U}$ and $V_{t}^{I}-V_{t}^{U}$, respectively.

Sectoral firm value functions are given by the hiring costs (see Blanchard and Gali (2010) for more detail):

$$
\begin{aligned}
& J_{t}^{F}=H C_{F, t} \\
& J_{t}^{I}=H C_{I, t}
\end{aligned}
$$

The underlying intuition is that a firm can always replace a worker by paying the hiring cost, as there is no search time required. 
Workers and firms bargain over real wages, given the above value functions:

$$
\begin{aligned}
& \max \left(V_{t}^{F}-V_{t}^{U}\right)^{\lambda_{F, t}}\left(J_{t}^{F}\right)^{1-\lambda_{F, t}} \\
& \max \left(V_{t}^{I}-V_{t}^{U}\right)^{\lambda_{I, t}}\left(J_{t}^{I}\right)^{1-\lambda_{I, t}}
\end{aligned}
$$

Two first-order bargaining conditions follow:

$$
\begin{aligned}
& \frac{\lambda_{F, t}}{1-\lambda_{F, t}}\left(1-\tau_{F, t}\right) J_{t}^{F}=V_{t}^{F}-V_{t}^{U} \\
& \frac{\lambda_{I, t}}{1-\lambda_{I, t}} J_{t}^{I}=V_{t}^{I}-V_{t}^{U}
\end{aligned}
$$

Only the formal sector' bargaining is affected by labor income taxes, as taxes are avoided in the informal sector.

\subsection{Retailers}

At the retailer level, there are $N_{F, t}$ monopolistic competitive firms which distribute at no cost wholesale goods purchased from the intermediate firms. Total demand for formal goods is denoted by $Q D_{F, t}$. We assume that the total final demand for formal goods is a Dixit and Stiglitz (1977) aggregator of the formal goods distributed by all final firms in the formal sector, where s denotes one of those firms:

$$
Q D_{F, t}=\left(\int_{0}^{N_{F, t}} Q D_{F, t}(s)^{\frac{\epsilon_{F, t}-1}{\epsilon_{F, t}}} d s\right)^{\frac{\epsilon_{F, t}}{\epsilon_{F, t}-1}}
$$

Here, the number of formal firms $N_{F, t}$ enters the aggregation because there is endogenous entry and the number of firms is not normalised to one. $\epsilon_{F, t}$ is the elasticity of substitution between goods in the formal sector. As usual, this elasticity is related to the price mark-up, which is $\frac{\epsilon_{F, t}}{\epsilon_{F, t}-1}$. We assume that this mark-up is endogenous and depends on the number of firms, i.e. $\epsilon_{F, t}=\alpha_{F} N_{F, t}$.

As a result of the retailer maximization problem, the aggregate price level is a function of the firms' price levels:

$$
P_{F, t}=\left(\int_{0}^{N_{F, t}} P_{F, t}(s)^{1-\epsilon_{F, t}} d s\right)^{\frac{1}{1-\epsilon_{F, t}}}
$$

and the relevant demand function is:

$$
Q D_{F, t}(s)=\left(\frac{P_{F, t}(s)}{P_{F, t}}\right)^{-\epsilon_{F, t}} Q D_{F, t}
$$

There is price stickiness at the retailer level; retailer firms set prices a la Rotemberg (1982). This means that there is a quadratic cost of price adjustment:

$$
R\left(P_{F, t}(s)=\frac{\phi_{F}}{2}\left(\frac{P_{F, t}(s)}{P_{F, t-1}(s)} \frac{1}{\pi}-1\right)^{2} Q D_{F, t}(s)\right.
$$


where the degree of price stickiness is $\phi_{F}$, and $\pi$ is the steady-state economy-wide inflation rate. Price adjustment positively depends on final demand as well.

Retailer $s$ maximises its expected discounted stream of future profits:

$$
\max E_{t} \sum_{k=t}^{\infty} Q_{t, k} \operatorname{Prof}_{F, k}^{R}(s)
$$

where $Q_{t, k}$ is the stochastic discount factor as before.

The one-period profit is given by:

$$
\operatorname{Prof}_{F, t}^{R}(s)=\left(\frac{P_{F, t}(s)}{P_{t}}-M C_{F, t}(s)\right)\left(\frac{P_{F, t}(s)}{P_{F, t}}\right)^{-\epsilon_{F, t}} Q D_{F, t}-R\left(P_{F, t}\right)(s)
$$

Here, $M C_{F, t}(s)$ is the price final firm $s$ pays when purchasing the wholesale goods. This is not equal to $M C_{F, t}$, but it is related to it through the number of final firms.

Specifically:

$$
M C_{F, t}=\left(\int_{0}^{N_{F, t}} M C_{F, t}(s)^{1-\epsilon_{F, t}} d s\right)^{\frac{1}{1-\epsilon_{F, t}}}
$$

This is a similar, Dixit and Stiglitz (1977)-type, expression that holds for $P_{F, t}$ as well.

As a result, the formal sector's pricing rule is:

$$
\begin{aligned}
& 1-\epsilon_{F, t}\left(\frac{P_{F, t}}{P_{t}}-M C_{F, t}\right)\left(\frac{P_{F, t}}{P_{t}}\right)^{-1}-\phi_{F}\left(\frac{P_{F, t}(s)}{P_{F, t-1}(s)} \frac{1}{\pi}-1\right) \frac{1}{\pi} \frac{P_{t}}{P_{F, t-1}(s)}+ \\
& +\beta \frac{C_{t}-h c C_{t-1}}{\zeta_{C, t}} E_{t}\left[\frac{\zeta_{C, t+1}}{C_{t+1}-h c C_{t}} \phi_{F}\left(\frac{P_{F, t+1}(s)}{P_{F, t}(s)} \frac{1}{\pi}-1\right) \frac{P_{F, t+1}}{P_{F, t}} \frac{N_{F, t}}{N_{F, t+1}} \frac{Q D_{F, t+1}}{Q D_{F, t}}\right]=0
\end{aligned}
$$

Then, product market regulation is modeled at the retailer level, and it follows Bilbie et al. (2012). A mass of firms potentially and endogenously enter the retailer market in every period. Entry is subject to an exogenous entry cost entry $y_{F, t}$. This entry cost consists of the costs to set up a new business, e.g. company registration, but also the administrative burden a firm assumes when starting a new company. This cost is the reason that the number of firms is not normalized to one, in contrast to a standard set-up without entry decision. Also, this is why the number of firms follows a law of motion described in the household sector.

New firms enter the market until the entry cost is equal to the firm value, which is the expected discounted value of future profits, taking into account the probability of going bankrupt:

$$
\begin{aligned}
& \text { entry }_{F, t}=E_{t} \sum_{k=t}^{\infty} Q_{t, k}\left(1-\delta_{F}\right)^{k-t+1} \operatorname{Prof}_{F, k}^{R}(s)= \\
& =\left(1-\delta_{F}\right) \operatorname{Prof}_{F, t}^{R}(s)+E_{t} Q_{t, t+1}\left(1-\delta_{F}\right) \text { entry }_{F, t+1}
\end{aligned}
$$

Here, $1-\delta_{F}$ enters the present value of future profits because the timing of retailers' decisions is as follow: first they decide whether to enter or not, then $1-\delta_{F}$ share of the new entrants does not go bankrupt and operates, finally all firms operating in period t decide on prices.

Deregulating the product market means that the fixed formal entry cost is decreased by the government. 


\subsection{Rest of the world, government, monetary authority and mar- ket clearings}

The home economy is a small open-economy. Consequently, it cannot affect foreign price level or foreign interest rate, which are exogenously given.

For the sake of simplicity, we assume that the aggregate export demand is:

$$
Q_{t}^{X}=\left(\frac{P_{F, t}}{e_{t} P_{t}^{\star} \alpha_{X}}\right)^{-\varsigma_{X}}
$$

where $\varsigma_{X}>0$ is the price elasticity and $\alpha_{X}$ is a parameter that captures factors other than the export price, which affect the export demand, e.g. the international economic environment. Because only formal goods are exported, the price of exports in foreign currency is $P_{F, t}^{\star}=\frac{P_{F, t}}{e_{t}}$; here $e_{t}$ is the nominal exchange rate, and we assume that the law of one price holds.

The exogenous foreign inflation is defined as $\pi_{t}^{\star}=\frac{P_{t}^{\star}}{P_{t-1}^{\star}}$.

Also, we assume that the import price of each company $s$ (by assumption the number of companies which import is equal to the number of formal goods producers) is related to the real exchange rate where $\varsigma_{M}$ captures the exchange rate pass-through to import prices:

$$
\frac{\frac{P_{f, t}(s)}{P_{t}}}{\frac{P_{f}(s)}{P}}=\left(\frac{R E R_{t}}{R E R}\right)^{\varsigma_{M}}
$$

Then, the final import price is a Dixit and Stiglitz (1977)-type aggregator of the individual import prices, namely:

$$
P_{f, t}=\left(\int_{0}^{N_{F, t}} P_{f, t}(s)^{1-\epsilon_{F, t}} d s\right)^{\frac{1}{1-\epsilon_{F, t}}}
$$

Finally, the interest rate on foreign bond holdings $i_{t}^{\star}$ depends not only on the exogenous foreign interest rate if $f_{t}$, but also on a premium $(\chi)$, following Schmitt-Grohe and Uribe (2003), whereby holders of foreign debt are assumed to face an interest rate that is increasing in the country's relative net foreign debt:

$$
\text { if } f_{t}=i_{t}^{\star}-\chi \frac{B_{t}-B}{\frac{P_{F}}{e P^{\star}} Q^{X}}
$$

The government sector is relatively simple, as the focus is on product and labor market regulations and not on the public sector. There is an exogenous stream of government consumption $G_{t}$ which is purchased both from the home formal sector and abroad:

$$
G_{t}=\left[\alpha^{\frac{1}{\eta}} G_{H, t}^{\frac{\eta-1}{\eta}}+(1-\alpha)^{\frac{1}{\eta}} G_{f, t}^{\frac{\eta-1}{\eta}}\right]^{\frac{\eta}{\eta-1}}
$$


Cost spent on government consumption goods is minimized, and this implies the usual demand functions:

$$
\begin{aligned}
G_{H, t} & =\alpha G_{t}\left(\frac{P_{F, t}}{P_{I N V, t}}\right)^{-\eta} \\
G_{f, t} & =(1-\alpha) G_{t}\left(\frac{P_{f, t}}{P_{I N V, t}}\right)^{-\eta}
\end{aligned}
$$

The price level of government consumption goods is the same as that of investment goods, and differs from that of household consumption goods, as the government does not buy informal goods.

Also, the government is responsible for financing social benefit expenditure to those who are not employed.

These government expenses are financed by a labor income tax - in the formal sector only - and a lump-sum tax. For simplicity's sake, we neglect consumption, capital and bond taxes. Also, we do not assume that the government has access to domestic or international bond markets.

So, the period-by-period government budget constraint is:

$$
\frac{P_{F, t}}{P_{t}} G_{t}+W U_{t} U_{t}=\operatorname{Tax}_{t}+\tau_{F, t} W F_{t} L_{F, t}
$$

Then, we consider a Taylor-type monetary policy rule following Smets and Wouters (2007):

$$
\frac{1+i_{t}}{1+i}=\left(\frac{1+i_{t-1}}{1+i}\right)^{\rho_{i}}\left[\left(\frac{\pi_{t}}{\pi}\right)^{\rho_{\pi}}\left(\frac{G D P_{t}}{G D P}\right)^{\rho_{G D P}}\right]^{1-\rho_{i}} e^{\epsilon_{i, t}}
$$

where $\rho_{i}$ captures interest rate smoothing, and the central bank responds to current inflation and GDP. $\epsilon_{i, t}$ is the monetary policy shock intended to capture unanticipated increases in the nominal interest rate. $\rho_{\pi}$ and $\rho_{G D P}$ are the weights on inflation and GDP, respectively.

Concerning market clearing, employment in the formal and in the informal sector adds up to total employment, which is one minus unemployment:

$$
\begin{aligned}
& L_{F, t}+L_{I, t}=L_{t} \\
& U_{t}=1-L_{t}
\end{aligned}
$$

Formal and informal capital demand add up to total capital supplied by capital producers. Then, there is equilibrium in the home bond market.

$$
\begin{aligned}
& K_{F, t}+K_{I, t}=K_{t} \\
& D_{t}=Q_{t} K_{t}
\end{aligned}
$$


The resource constraint for the formal sector is given by:

$$
\begin{aligned}
& Y_{F, t}=Q D_{F, t}+H C_{F, t} H_{F, t} \frac{P_{t}}{P_{F, t}}+N_{F, t}^{E} \text { entry }_{F, t} \frac{P_{t}}{P_{F, t}}+ \\
& +\frac{\phi_{F}}{2}\left(\frac{P_{F, t}(s)}{P_{F, t-1}(s)} \frac{1}{\pi}-1\right)^{2} Q D_{F, t}(s) N_{F, t} \frac{P_{t}}{P_{F, t}}
\end{aligned}
$$

where $Q D_{F, t}=C_{F, t}+I_{H, t}+G_{H, t}+Q_{t}^{X}$, which means that the total demand for formal goods is equal to the sum of home demand (demand by consumers, firms and the government) and export demand. This constraint means that the amount of goods produced in the formal sector is equal to the amount of formal goods demanded by the home and foreign economy. There are three deadweight losses, too: first, labor market frictions; second, entry cost; and third, the Rotemberg price adjustment cost.

A similar constraint holds for the informal sector as well:

$$
\begin{aligned}
& Y_{I, t}+Y_{H P, t}=Q D_{I, t}+H C_{I, t} H_{I, t} \frac{P_{t}}{P_{I, t}}+N_{I, t}^{E} \text { entry }_{I, t} \frac{P_{t}}{P_{I, t}}+ \\
& +\frac{\phi_{I}}{2}\left(\frac{P_{I, t}(s)}{P_{I, t-1}(s)} \frac{1}{\pi}-1\right)^{2} Q D_{I, t}(s) N_{I, t} \frac{P_{t}}{P_{I, t}}
\end{aligned}
$$

where $Q D_{I, t}=C_{I, t}$ is the total demand for informal goods.

The main difference between formal and informal constraints is that home production $Y_{H P, t}$ enters the informal resource constraint. This is necessary to close the model, while the intuitive reason behind it is the fact that people also work at home. Here, we follow Cacciatore and Fiori (2016). Also, in line with the aforementioned paper, we assume that the value of home production is equal to a fraction $\alpha_{H P}$ of the product of average wage and the number of unemployed people in each period:

$$
Y_{H P, t}=\alpha_{H P} \frac{W F_{t} L_{F, t}+W I_{t} L_{I, t}}{L_{t}} U_{t}
$$

This means that we assume that those who work at home (and for the sake of simplicity we equalize the number of unemployed to the number of working at home) "earn" the average economy-wide wage level.

Total import is a sum of imported consumption, investment and government goods:

$$
Q_{t}^{M}=C_{f, t}+I_{f, t}+G_{f, t}
$$

Finally, total home output and GDP are given by:

$$
\begin{aligned}
& P_{H, t} Y_{t}=P_{F, t} Y_{F, t}+P_{I, t} Y_{I, t} \\
& G D P_{t}+\frac{P_{f, t}}{P_{t}} Q_{t}^{M}=C_{t}+\frac{P_{I N V, t}}{P_{t}}\left(I_{t}+G_{t}\right)+\frac{P_{F, t}}{P_{t}} Q_{t}^{X}
\end{aligned}
$$

\subsection{The role of informality of openness}

Table 1 summarizes the differences between the formal and informal sectors. First, the level of regulation, related to hiring, firing and entry, in line with Williamson (1975), are 
lower in the shadow economy. On the one hand, formal-sector firms incur greater hiring costs than do firms in the informal sector. These costs can be associated with training to make up for educational or experiential deficits on the worker's part, but they might reflect as well administrative costs such as time spent on hiring. Then too, the bargaining power of workers in wage setting is higher in the formal than in the informal economy. The strength of unions in the formal sector might be at play here, but this relative bargaining clout can also be related to the sector's legal environment, which provides more rights for workers than firms in setting wages. Employment protection might also be reflected in the fact that the probability of firing is lower in the formal sector. Furthermore, registering a new company is costly, in terms of both money and time. Hence, formal entry costs are larger than informal ones. Finally, price mark-up is higher and firm exit rate, similarly to the dismissal rate of workers, is lower in the formal sector than in the underground economy.

\begin{tabular}{lcc}
\hline & Formal sector & Informal sector \\
\hline Entrepreneurs' labor hiring costs & High & Low \\
Workers' bargaining power over wages & High & Low \\
Probability of firing workers & Low & High \\
Retailers' entry costs & High & Low \\
Retailers' price markup & High & Low \\
Retailers' exit rate & Low & High \\
Labor productivity & High & Low \\
Taxation & Yes & No \\
Traded & Yes & No \\
Government consumption & Yes & No \\
Physical capital production & Yes & No
\end{tabular}

Table 1: Formal and informal rigidities

Alongside differences in regulation levels, other features serve to distinguish the two sectors. Notably, only formal sector's labor income falls under the taxation umbrella. Also, the government can only purchase formal goods, and, by virtue of administrative regulations in the formal sector, physical capital investment is made solely on the basis of formal goods. Another reason for that might be that informal enterprises often do not have access to financing (see for instance La Porta and Shleifer (2008)). As well, labor productivity in the informal sector is lower than in the formal sector. Finally, formal goods are traded abroad, but informal goods are not. This is likely to be explained by the fact that entering the foreign markets requires the meeting of certain legal obligations. The fact that only formal goods are traded abroad constitutes the main example in our model of interactions between the shadow economy and openness.

Due to the model's complexity, we are unable to examine analytically the mechanisms induced by the presence of informality or openness. Nevertheless, we provide simulation results in three parametrized economies: a baseline open-economy model with a shadow sector, an alternative closed-economy model with the same shadow sector, and an another alternative open-economy model where the size of shadow output is $1 / 3$ of that of the baseline value ${ }^{14}$.

\footnotetext{
${ }^{14}$ Tables A2 and A3 in the Appendix show the steady-state and dynamic parameters of the three parametrized economies.
} 
Table 2 shows the long-run (25-year) effects of sreforms; deterministic simulations were carried out by Dynare 4.4.3. Reforms are: a 10 percent permanent and unexpected reduction in the formal (i) hiring cost, (ii) bargaining power of workers, and (iii) entry cost. ${ }^{15}$

\begin{tabular}{|c|c|c|c|c|c|c|}
\hline \multicolumn{2}{|c|}{$\begin{array}{l}\text { Long-run effects of lowering the } \\
\text { formal }\end{array}$} & \multirow{2}{*}{\begin{tabular}{|c|} 
GDP, $\%$ \\
1.0
\end{tabular}} & \multirow{2}{*}{$\begin{array}{c}\text { Unemployment, } \\
\text { \%point }\end{array}$} & \multirow{2}{*}{$\begin{array}{c}\begin{array}{c}\text { Formal } \\
\text { employment, } \\
\text { \%point }\end{array} \\
1.0\end{array}$} & \multirow{2}{*}{$\begin{array}{c}\begin{array}{c}\text { Informal } \\
\text { employment, } \\
\text { \%point }\end{array} \\
0.1\end{array}$} & \multirow{2}{*}{$\begin{array}{c}\begin{array}{c}\text { Formal } \\
\text { wage, } \%\end{array} \\
-0.4\end{array}$} \\
\hline \multirow{4}{*}{$\begin{array}{l}\text { hiring cost } \\
\text { bargaining power } \\
\text { of workers }\end{array}$} & \begin{tabular}{l|l} 
Baseline & \\
\end{tabular} & & & & & \\
\hline & Low informality & 1.7 & -1.7 & 1.7 & 0.0 & -0.2 \\
\hline & Baseline & 1.8 & -2.4 & 2.0 & 0.4 & -1.5 \\
\hline & Low informality & 2.8 & -3.3 & 3.2 & 0.0 & -1.4 \\
\hline \multirow{2}{*}{ entry cost } & Baseline & 0.5 & -0.2 & 0.2 & 0.0 & 0.4 \\
\hline & Low informality & 0.8 & -0.4 & 0.4 & 0.0 & 0.5 \\
\hline \multicolumn{2}{|c|}{$\begin{array}{l}\text { Long-run effects of lowering the } \\
\text { formal }\end{array}$} & $\begin{array}{l}\text { Informal } \\
\text { wage, } \%\end{array}$ & $\begin{array}{c}\text { Number of } \\
\text { formal firms, \% }\end{array}$ & $\begin{array}{l}\text { Number of } \\
\text { informal } \\
\text { firms, \% }\end{array}$ & $\begin{array}{l}\text { Net exports, } \\
\text { \%point }\end{array}$ & $\begin{array}{c}\text { Investment, } \\
\%\end{array}$ \\
\hline \multirow{4}{*}{$\begin{array}{l}\text { hiring cost } \\
\text { bargaining power } \\
\text { of workers }\end{array}$} & Baseline & 0.2 & 0.6 & 0.3 & 0.3 & -0.1 \\
\hline & Low informality & 0.5 & 0.9 & 0.2 & 0.4 & -0.1 \\
\hline & Baseline & 0.0 & 1.0 & 0.7 & 0.4 & 0.4 \\
\hline & Low informality & 0.8 & 1.5 & 0.3 & 0.5 & 0.4 \\
\hline \multirow{2}{*}{ entry cost } & \begin{tabular}{|l|} 
Baseline \\
\end{tabular} & 0.4 & 5.7 & 0.2 & 0.1 & 0.2 \\
\hline & Low informality & 0.2 & 5.8 & 0.2 & 0.1 & 0.2 \\
\hline \multicolumn{2}{|c|}{$\begin{array}{l}\text { Long-run effects of lowering the } \\
\text { formal }\end{array}$} & GDP, $\%$ & $\begin{array}{c}\text { Unemployment, } \\
\text { \%point }\end{array}$ & $\begin{array}{c}\text { Formal } \\
\text { employment, } \\
\text { \%point }\end{array}$ & $\begin{array}{c}\text { Informal } \\
\text { employment, } \\
\text { \%point }\end{array}$ & $\begin{array}{c}\text { Formal } \\
\text { wage, \% }\end{array}$ \\
\hline \multirow{4}{*}{$\begin{array}{l}\text { hiring cost } \\
\text { bargaining power } \\
\text { of workers }\end{array}$} & Baseline & 1.0 & -1.2 & 1.0 & 0.1 & -0.4 \\
\hline & Closed economy & 1.1 & -1.0 & 0.8 & 0.2 & -0.3 \\
\hline & Baseline & 1.8 & -2.4 & 2.0 & 0.4 & -1.5 \\
\hline & Closed economy & 1.9 & -2.0 & 1.5 & 0.6 & -1.2 \\
\hline \multirow{2}{*}{ entry cost } & Baseline & 0.5 & -0.2 & 0.2 & 0.0 & 0.4 \\
\hline & Closed economy & 0.4 & -0.1 & 0.2 & 0.0 & 0.3 \\
\hline \multicolumn{2}{|c|}{$\begin{array}{l}\text { Long-run effects of lowering the } \\
\text { formal }\end{array}$} & $\begin{array}{l}\text { Informal } \\
\text { wage, \% }\end{array}$ & $\begin{array}{c}\text { Number of } \\
\text { formal firms, \% }\end{array}$ & $\begin{array}{c}\text { Number of } \\
\text { informal } \\
\text { firms, \% }\end{array}$ & $\begin{array}{c}\text { Net exports, } \\
\text { \%point }\end{array}$ & $\begin{array}{c}\text { Investment, } \\
\%\end{array}$ \\
\hline \multirow{4}{*}{$\begin{array}{l}\text { hiring cost } \\
\text { bargaining power } \\
\text { of workers }\end{array}$} & \begin{tabular}{|l|} 
Baseline \\
\end{tabular} & 0.2 & 0.6 & 0.3 & 0.3 & -0.1 \\
\hline & Closed economy & 0.3 & 0.7 & 0.4 & - & 0.0 \\
\hline & Baseline & 0.0 & 1.0 & 0.7 & 0.4 & 0.4 \\
\hline & Closed economy & 0.3 & 1.1 & 0.7 & - & 0.4 \\
\hline \multirow{2}{*}{ entry cost } & Baseline & 0.4 & 5.7 & 0.2 & 0.1 & 0.2 \\
\hline & Closed economy & 0.3 & 5.7 & 0.1 & - & 0.2 \\
\hline
\end{tabular}

Table 2: The role of shadow economy and openness in long-run (25-year) effects of labor and product market reforms. Policies are done in the formal sector and mean permanent unexpected 10 percent reforms. Low informality means that the size of shadow output is $1 / 3$ of the baseline.

\footnotetext{
${ }^{15}$ Fiscal consolidation policies are easy to compare in the sense that all of them can be expressed in GDP size. The size of deregulation policies, however, is less straightforward to compare. A 10 percent decrease in hiring cost means that the hiring cost is 10 percent lower compared to wages. A 10 percent decrease in workers' bargaining power means that workers have 10 percent less power in wage setting. While entry cost is typically calculated as a share in production. Hence, in terms of GDP, the sizes of these shocks might differ. The same note holds for Section 2.4.
} 
First, in the long-run, macroeconomic impacts in the open-and closed-economy models are quite similar. The only exceptions are the labor market reactions of the bargaining power of workers policy. ${ }^{16}$

On the other hand, the shadow economy crucially influences the reactions. This is especially true for labor market policies, but also responses of product market deregulation are affected. Notably, GDP goes up by 1 or 1.8 per cent in the long-run, if hiring costs or bargaining power of workers in the formal sector are lowered, respectively; while the same effects are 1.7 and 2.8 per cent if the size of the shadow economy is $1 / 3$ of the original level. As regards unemployment, the presence of informality is not less important. A 10 per cent reduction in hiring costs implies a $1.7 \mathrm{pp}$ drop in the rate of unemployment with low informality, while in the baseline scenario unemployment only goes down by $1.2 \mathrm{pp}$. Also, a bargaining power policy induces 3.3 and $2.4 \mathrm{pp}$ decreases in unemployment, respectively. Similarly, formal employment is also essentially affected, for instance a bargaining power policy induces a 3.2 $\mathrm{pp}$ drop in formal employment with low informality, but only a 2 pp drop with high informality.

The main reason is that the lower the size of the shadow economy, the larger the share of the economy directly affected by structural reforms; and, this outweighs other channels in the model. Thus, in a model that does not (or does not fully) incorporate the underground sector, macroeconomic impacts seem to be larger than they really are. Because the model behaves as if some part of the macroeconomy was formal, even though it is informal.

Short-run dynamics are also influenced by the presence of informality; impulse responses with low informality are about 0.5-1 pp higher (Figures A1 and A2 in the Appendix). Additionally, labor market reforms do not raise informal employment; while informal wages go up instead of down if the bargaining power of workers is lowered. Also, inflation goes up more with low informality. Then, as regards deregulating the product markets, in the baseline scenario GDP increases immediately after the shock, with low informality, however, during the first couple of quarters it decreases. It means that there is a severe cost during the transition towards the post-reform equilibrium. It happens because, on the one hand, investment declines ${ }^{17}$, on the other hand, unemployment drops more than before.

On the whole, we can conclude that informality is crucial for the sign, and, in particular, the magnitude of macroeconomic responses to structural reforms.

\section{Calibration and Bayesian estimation}

In this section, we describe calibration of steady-state parameters and Bayesian estimation of dynamic parameters. We consider quarterly data on South Africa, which is a small openeconomy and serves as an example of the emerging world, where the underground economy plays, in general, a stronger role than it does in developed countries. When calibrating the steady state, our main goal is to match, as accurately as possible, data on unemployment and the size of shadow economy.

\footnotetext{
${ }^{16}$ Note that the model has a simple trade sector that largely depends on exogenous processes.

${ }^{17}$ We would like to note that investment only slightly changes both in the baseline and the alternative scenarios.
} 


\begin{tabular}{|c|c|c|c|}
\hline Variable (\%) & Data & Data source and year & Model \\
\hline Private investment as a share of GDP & 17.8 & & 22.6 \\
\hline Openness as a share of GDP & 54.3 & South African Reserve Bank, 2000Q3-2012Q2 & 59.2 \\
\hline Unemployment rate & 28.7 & & 25.5 \\
\hline \multirow{5}{*}{ Shadow economy as a share of GDP } & 27.3 & Schneider et al. (2010) & 27.2 \\
\hline & 15.8 & University of Stellenbosch, 1996-2012 & \\
\hline & 18.3 & Department of Trade and Industry (2008) & \\
\hline & 17.0 & McKeever (1998) & \\
\hline & 19.0 & Kingdon and Knight (2001) & \\
\hline \multirow{5}{*}{$\begin{array}{l}\text { Shadow employment as a share of } \\
\text { total employment }\end{array}$} & $14.5-21.3$ & Casale et al. (2004) & 37.2 \\
\hline & 30.0 & Wills (2009) & \\
\hline & 33.0 & Chen et al. (2014) & \\
\hline & 33.0 & International Labor Organization (2013) & \\
\hline & 34.6 & Cassim et al. (2016) & \\
\hline
\end{tabular}

Table 3: Evaluating the steady state of the model

First, according to the Labor Force Survey (LFS) of the South African Reserve Bank, unemployment is pretty stable; during the last two decades it hovered around 28.7 percent, with a low dispersion around this mean (Table 3$).{ }^{18}$ As regards formal and informal employment, the available empirical information is mixed. ${ }^{19}$ According to the University of Stellenbosch, the share of informal employment in the South African labor force is fairly low (15.8 percent). At the same time, Cassim et al. (2016) report that informality in the labor market is 34.6 percent. And, there are a couple of estimates between. In terms of GDP, Schneider et al. (2010) finds that the size of the shadow economy is 27.3 percent.

First of all, we aim to match the size of the shadow economy in GDP, and the model does a very good job at it. Regarding shadow employment, its share in total employment is closest to that of Cassim et al. (2016). At the same time, unemployment is slightly underestimated. ${ }^{20}$ As a cross-check, we also had a look at investment to GDP ratio (the only big ratio which is not fixed during calibration); which is slightly higher in the model than in the data.

Now, turning to describing the process of calibration; Table 4 provides an overview of it. ${ }^{21}$

First, we estimate sectoral firing probabilities using LFS data on the number of job losers and on the number of new entrants among the unemployed, as well as data on formal and informal employment published by the Statistics of South Africa (SSA). Based on our own estimates, the probability of firing is 14.5 percent in the formal sector and 84.8 percent in the informal sector.

\footnotetext{
${ }^{18}$ In LFS, by design, those who are unemployed do not work in parallel (not even in the shadow economy). Hence, we believe that there is no significant overlap between the number of unemployed and the number of informally employed people in this survey.

${ }^{19}$ And, in general, both methodologies using macroeconomic data, and micro-level surveys have limitations, see e.g. Schneider and Enste (2000).

${ }^{20}$ The Technical Appendix shows evidence on the robustness of long-run macroeconomic impacts of structural reforms with respect to the assumptions we made during calibrating the steady state of the model.

${ }^{21}$ In this section we discuss parameters related to regulation, informality and openness. Nevertheless, Table 4 shows all parameter values, including those which are standard in the literature or are functional form assumptions (when no data source is indicated).
} 


\begin{tabular}{|c|c|c|c|c|}
\hline $\begin{array}{l}\text { Name of } \\
\text { fixed or calibrated parameter or variable }\end{array}$ & Sign of & Value & Source & Year \\
\hline Discount factor & $\beta$ & 0.99 & & \\
\hline Physical capital depreciation rate & $\delta$ & 0.025 & & \\
\hline Formal capital income share & $\psi_{\bar{F}}$ & 0.3 & & \\
\hline Informal capital income share & $\psi_{I}$ & 0.2 & & \\
\hline Markup in formal sector $(\%)$ & $\varepsilon_{\bar{F}}$ & 10 & & \\
\hline Markup in informal sector (\%) & $\varepsilon_{\mathrm{I}}$ & 5 & & \\
\hline Formal productivity level & $\theta_{F}$ & 1 & & \\
\hline Informal productivity level & $\theta_{\mathrm{I}}$ & 1 & & \\
\hline Formality bias & $\mu_{\bar{F}}$ & 0.5 & & \\
\hline Home inflation $(\%, Q \circ Q)$ & $\pi$ & 1.26 & Statistics South Africa & $2000 \mathrm{Q} 3-2012 \mathrm{Q} 2$ \\
\hline Exchange rate depreciation rate $(\%, Q \circ Q)$ & & 0.19 & South African Reserve Bank & 2000Q3-2012Q2 \\
\hline Exit rate of informal retailers & $\delta_{\mathrm{I}}$ & 0.1728 & $\begin{array}{l}\text { Authors' calculation based on data } \\
\text { of Companies and Intellectual } \\
\text { Property Commission and } \\
\text { Statistics South Africa (2006, }\end{array}$ & $2000-2012$ \\
\hline $\begin{array}{l}\text { Household consumption expenditure to GDP } \\
\text { ratio (\%) }\end{array}$ & & 63.97 & South African Reserve Bank & 2000Q3-2012Q2 \\
\hline $\begin{array}{l}\text { Government consumption expenditure to } \\
\text { GDP ratio (\%) }\end{array}$ & & 19.80 & South African Reserve Bank & 2000Q3-2012Q2 \\
\hline Exports to GDP ratio (\%) & $a_{\mathrm{x}}$ & 26.40 & South African Reserve Bank & $2000 \mathrm{Q} 3-2012 \mathrm{Q} 2$ \\
\hline Public social protection to GDP ratio (\%) & & 5.06 & International Labor Organization & $1995-2005$ \\
\hline Firing probability in the formal sector & probf $_{\bar{F}}$ & 0.1446 & Authors' calculation based on LFS & 2008Q1-2012Q4 \\
\hline Firing probability in the informal sector & probf $_{\mathrm{I}}$ & 0.848 & data of Statistics South Africa & $2000 Q^{1-2012} \mathrm{Q}^{4}$ \\
\hline Ratio of hiring cost in wage in formal sector & & 1.6849 & $\begin{array}{l}\text { World Economic Forum's Global } \\
\text { Competitiveness Index Historical }\end{array}$ & $2006-2013$ \\
\hline Ratio of hiring cost in wage in informal sector & & 0.8425 & Dataset & \\
\hline $\begin{array}{l}\text { Elasticity of substitution between home and } \\
\text { foreign goods }\end{array}$ & $\mu$ & 0.6 & Steinbach et al (2009) & \\
\hline Home bias & a & 0.8 & Steinbach et al (2009) & \\
\hline Export price elasticity & $\varsigma \mathrm{x}$ & 4.5 & Behar-Edwards (2004) & \\
\hline Share of income tax revenue in GDP (\%) & $\tau_{\bar{F}}$ & 9 & Badaoui-Magnani (2013) & \\
\hline Exchange rate pass-through to import prices & $c_{\mathrm{M}}$ & 0.812 & Karoro et al (2008) & \\
\hline $\begin{array}{l}\text { Entry cost in the formal sector (in months of } \\
\text { production) } \\
\text { Entry cost in the informal sector (in months } \\
\text { of production) }\end{array}$ & & $\begin{array}{l}2.07 \\
1.04\end{array}$ & Cacciatore-Fiori (2016) & \\
\hline Share of home production in average wage & & 25 & Cacciatore-Fiori (2016) & \\
\hline $\begin{array}{l}\text { Elasticity of hiring cost wrt to hiring } \\
\text { probability (formal) }\end{array}$ & $a_{\mathrm{HCT}}$ & 0.5 & & \\
\hline $\begin{array}{l}\text { Elasticity of hiring cost wrt to hiring } \\
\text { probability (informal) }\end{array}$ & $a_{\text {HCI }}$ & 0.5 & & \\
\hline $\begin{array}{l}\text { Elasticity of substitution between formal and } \\
\text { informal goods }\end{array}$ & $\eta$ & 1.5 & & \\
\hline Formal bargaining power of workers & $\lambda_{F}$ & 0.6 & & \\
\hline Informal bargaining power of workers & $\lambda_{\mathrm{I}}$ & 0.4 & & \\
\hline
\end{tabular}

Table 4: Calibration of steady-state parameters based on South African data 
Regrettably, we are not aware of any empirical information on hiring costs. Nevertheless, the Global Competitiveness Report of the World Economic Forum provides data on firing costs; since 2006 redundancy costs were 21.9 weeks of salary on average. This means that the ratio of firing costs to quarterly wages was 1.7 . Assuming that hiring costs are at a similar magnitude, we use this ratio to calibrate them compared to wages in the formal sector. In light of the dearth of data regarding the informal sector, we assume that the fraction of hiring costs to wages is half as much in the informal as in the formal sector.

Furthermore, information regarding bargaining power of workers in South Africa is also unknown to us. In the literature, it is usually between 0.3 and 0.5 (Mortensen and Nagypal, 2007). Because we assume that workers in the formal sector have more bargaining power in wage setting than do workers in the informal sector. We set the formal bargaining power of workers to 0.6 and the relevant informal value to 0.4 to match labor market characteristics as accurately as possible.

Regarding sectoral bankruptcy rates, we follow data on the number of new and total firms; published by i) the Companies and Intellectual Property Commission's and ii) SSA (2006), SSA (2010) and SSA (2014). Based on these, we estimate the bankruptcy rates to be 10.9 percent in the formal sector and 17.3 percent in the informal sector.

As regards the level of entry costs, we are not aware of data for South Africa, either. However, Cacciatore and Fiori (2016) claim that, in the euro area, the entry cost of new companies is equal to about 2.1 months of yearly output. We use this value as a proxy to calibrate the steady-state level of formal entry costs, while we assume that the informal entry cost-output ratio is half of the formal sector's value.

In the absence of data, the formality bias, i.e. the share of formal goods in household and government consumption, is normalized to 50 percent. Furthermore, we assume that the elasticity of substitution between formal and informal goods is 1.5 , which is in the range of usual values of the literature. We do not set this elasticity to one, because we believe that when purchasing informal goods personal relations between sellers and buyers also matter (but we check the robustness of our results with a unit elasticity).

Finally, concerning openness, home bias is 0.8 , i.e. the share of imported goods is 20 percent, while the elasticity of substitution between home- and foreign-produced goods is 0.6 . Both values follow Steinbach et al. (2009). Then, export price elasticity is 4.5, in line with Behar and Edwards (2004), and the exchange rate pass-through to import prices is slightly above 0.8 according to Karoro et al. (2008).

Now, concerning the dynamic structural parameters, they are Bayesian estimated using Dynare 4.4.3. Priors and posteriors are shown in Table 5. ${ }^{22}$

Bayesian estimation was done by using the following quarterly time series; the time span was between 2000Q3 and 2012Q2 (data sources are in parenthesis):

- gross domestic product (International Monetary Fund, IMF)

\footnotetext{
${ }^{22}$ Also, see Figure A3 and Tables A4-A5 in the Appendix. Priors of Rotemberg price adjustment costs are based on priors of Calvo price rigidities (equal to 50 percent), and the levels of price mark-ups, following Lombardo and Vestin (2007).
} 
- household consumption expenditure, government consumption expenditure, private investment, exports and imports of goods and services (South African Reserve Bank, SARB)

- real exchange rate (SARB)

- consumer price index (SSA)

- treasury bill rate (IMF)

- compensation of employees in the formal sector (SARB)

- formal and informal employment (SSA and own estimates)

\begin{tabular}{|c|c|c|c|c|c|c|c|}
\hline & \multirow[b]{2}{*}{ Structural parameters } & \multirow[b]{2}{*}{ distribution } & \multicolumn{2}{|c|}{ prior } & \multicolumn{3}{|c|}{ posterior } \\
\hline & & & mean & $\begin{array}{l}\text { standard } \\
\text { deviation }\end{array}$ & mean & confiden & interval \\
\hline $\mathrm{h}$ & consumption habit & beta & 0.7 & 0.2 & 0.89 & 0.89 & 0.90 \\
\hline$\gamma_{\mathrm{i}}$ & interest rate smoothing & beta & 0.7 & 0.2 & 0.16 & 0.04 & 0.28 \\
\hline$\gamma_{\pi}$ & inflation response & gamma & 2 & 0.5 & 3.05 & 2.42 & 3.64 \\
\hline$\gamma_{\mathrm{Y}}$ & output response & gamma & 0.1 & 0.1 & 0.35 & 0.24 & 0.48 \\
\hline $\mathrm{dF}$ & formal Rotemberg cost & gamma & 19.80 & 10 & 1.80 & 0.79 & 2.77 \\
\hline dI & informal Rotemberg cost & gamma & 36.60 & 20 & 5.05 & 1.73 & 8.78 \\
\hline$\chi$ & interest rate premium & inverse gamma & 0.002 & 0.001 & 0.002 & 0.001 & 0.002 \\
\hline$\zeta$ & investment adjustment cost & gamma & 0.5 & 0.2 & 0.60 & 0.37 & 0.84 \\
\hline
\end{tabular}

Table 5: Prior and posterior distributions of structural dynamic parameters. The priors of consumption habit and interest rate smoothing are maximized to 0.9 , while the prior of interest rate premium is maximized to 0.005 .

Three caveats apply. First, all national accounts' time series are expressed in real terms, in 2005 prices and in South African RAND. Next, all time series are seasonally adjusted and divided by the number of population (if necessary). Finally, all time series are official data, except formal and informal employment, which are estimated by the authors before 2008Q2. ${ }^{23}$

\section{Long- and short-run effects of deregulation policies in South-Africa}

Permanent and unexpected reforms are carried out in the labor and product markets; and, we do not only study their long-run (25-year) impact, but also the transition (especially the first 5 years) between the pre-reform and post-reform equilibria. All shocks are implemented in the formal sector, while in the papers without informality policies were defined at the aggregate level. Regarding the size of the reforms, the level of regulation (hiring cost, bargaining power of workers, or entry cost) is reduced by 10 percent. ${ }^{24}$ First, single policies, then reform packages are studied; the latter to see to what extent and in which parts of the economy shortterm costs can be mitigated. Finally, we explore policy sequencing, with a special interest in the speed of adjustment, which is defined as the pace the country needs to move from the prereform to the post-reform equilibria. Deterministic simulations were done by Dynare 4.4.3.

${ }^{23}$ Quarterly formal and informal employment data published by SSA is available since 2008Q2. First, based on yearly data, ordinary least-squares regressions of formal and informal employment (data source is DTI) on GDP, (formal) compensation of employees and inflation are estimated. Then, using these coefficients and quarterly data on GDP, (formal) compensation of employees and inflation between 2003Q3 and 2012Q2, and formal and informal employment between 2008Q2 and 2012Q2, we estimate quarterly formal and informal employment between 2003Q3 and 2008Q1.

${ }^{24}$ See footnote 15 . 


\subsection{Long-run effects of single reforms}

Table 6 shows the macroeconomic impacts of deregulation policies in the long run. ${ }^{25}$ Specifically, permanently lowering the hiring cost in the formal sector by 10 percent results in a 2.9 percent increase in GDP 25 years post-policy implementation. A 10 percent reduction in the formal bargaining power of workers increases GDP by 3.3 percent, while decreasing the formal entry cost by 10 percent implies a 1.1 percent rise in output. Regarding unemployment, lowering the hiring cost, the bargaining power of workers, or the entry cost in the formal sector brings about a $2.8,4.6$ or 0.5 pp decline in the rate of unemployment, respectively.

The mechanisms behind labor and product market reforms are different, and sectoral reactions also differ. Labor market reforms imply a decline in long-run wages. A lower formal bargaining power of workers results in a lower formal wage, because firms have more power to control wages. Similarly, when formal hiring costs go down, firms want to cut down wages, too; for example because a lower hiring cost means that it is less important to keep the workers today (it is less costly to re-hire them in the future). At the same time, product market reforms imply a rise in competition (in both sectors, but more in the formal sector). Formal wages go up; larger demand and production require to attract new workers. Informal wages always go up (but they go up less after a product market reform); workers tend to move out of informality - although to a small extent - and firms try to keep them this way.

The employment reaction is, obviously, strongly related to that of wages. Notably, unemployment decreases more after a labor market reform, consistently with the decline in formal wages there. Reducing hiring costs in the formal sector not only reduces the relative cost of labor to capital, but it also encourages workers to move to the more productive formal sector. The latter is less true when formal entry costs are lowered. Hence, while all policies increase both formal and informal employment, formal employment increases more. That is to say, previously unemployed people begin working in the official economy, while the level of underground employment is largely unaffected. However, as a consequence, its share still considerably drops. As well, formality in the labor market increases more with a labor market, as compared to a product market, reform.

As both reforms are effective in decreasing unemployment, both reforms are suitable to increase competition. Still, as a labor market reform is more successful in lowering unemployment, because it directly affects the labor market (and only indirectly other markets), a product market reform is more successful in achieving higher competition, because it is carried out in the goods market.

Finally, as formal firms can have access to foreign markets, a decrease in the size of shadow economy implies a positive response of net exports, too, and, it is true for any policy we consider.

Our conclusions sometimes converge with, while sometimes diverge from those found in the literature. ${ }^{26}$ First, we find that a product market reform seems to be less successful in

\footnotetext{
${ }^{25}$ Note that, in the long run, household consumption changes as GDP does as because we assume that the ratio of household consumption to GDP is constant.

${ }^{26}$ Importantly, comparisons are not always straightforward, because different policies, or the same policies but with different dimensions, are implemented. As well, we compare our findings to those based on other general equilibrium frameworks, but there are works with partial equilibium models as well. One example is Berger and
} 
increasing employment; this is consistent with Charlot et al. (2015), but in contrary to Cacciatore et al. (2016b) or Lusinyan and Muir (2013). The reason behind this might be that the latter do not take informality into account, hence, the fact that after a labor market reform workers move to the more productive formal sector is not considered (also Lusinyan and Muir (2013) find a sizeable increase in wages when competition increases, which we do not find). In addition, Ebell and Haefke (2009) also claim that product market reforms have a small impact on unemployment only, although according to Ebell and Haefke (2006) the extent depends on the type of bargaining mechanism.

\begin{tabular}{|c|c|c|c|c|c|}
\hline $\begin{array}{c}\text { Long-run effects } \\
\text { when lowering } \\
\text { the ... }\end{array}$ & GDP, $\%$ & $\begin{array}{c}\text { Unemployment, } \\
\text { \%point }\end{array}$ & $\begin{array}{c}\text { Formal } \\
\text { employment, } \\
\text { \%point }\end{array}$ & $\begin{array}{c}\text { Informal } \\
\text { employment, } \\
\text { \%point }\end{array}$ & $\begin{array}{c}\text { Formal } \\
\text { wage, \% }\end{array}$ \\
\hline hiring cost & 2.9 & -2.8 & 2.2 & 0.6 & -0.9 \\
\hline $\begin{array}{l}\text { bargaining } \\
\text { power of }\end{array}$ & 3.3 & -4.6 & 3.8 & 0.8 & -5.3 \\
\hline entry cost & 1.1 & -0.5 & 0.3 & 0.2 & 0.8 \\
\hline $\begin{array}{c}\text { Long-run effects } \\
\text { when lowering } \\
\text { the ... }\end{array}$ & $\begin{array}{l}\text { Informal } \\
\text { wage, } \%\end{array}$ & $\begin{array}{c}\text { Number of } \\
\text { formal firms, \% }\end{array}$ & $\begin{array}{l}\text { Number of } \\
\text { informal } \\
\text { firms, } \%\end{array}$ & $\begin{array}{c}\text { Net exports, } \\
\text { \%point }\end{array}$ & $\begin{array}{c}\text { Investment, } \\
\%\end{array}$ \\
\hline hiring cost & 1.8 & 1.6 & 1.1 & 0.8 & 2.9 \\
\hline $\begin{array}{l}\text { bargaining } \\
\text { power of }\end{array}$ & 2.5 & 1.8 & 1.1 & 0.5 & 5.4 \\
\hline entry cost & 0.5 & 6.0 & 0.5 & 0.2 & 1.3 \\
\hline
\end{tabular}

Table 6: Long-run (25-year) effects of single structural reforms in South Africa. All deregulation policies are implemented in the formal sector, and mean a permanent and unexpected 10 percent reforms.

Our findings are in line with Charlot et al. (2015) in the sense that they claim that both deregulations decrease both the size of the informal sector and unemployment. However, contrary to them we cannot generally conclude that a labor market deregulation has a negative effect on wages. This is only true for formal wages, while informal wages always go up. At the same time, we find that a product market deregulation has a positive impact on wages in both sectors.

\subsection{Short-run effects of single reforms}

While there are considerable long-term gains of deregulation in the form of an increase in output or a decrease in unemployment, also, shadow employment becomes less significant, short-term costs emerge during the transition (Figure 5).

First, GDP significantly declines during the first year when the bargaining power of workers is lowered, while it slightly declines with a hiring cost cut. Nevertheless, thanks to a greater increase in formal employment, the reaction of unemployment is similar. Also, shadow employment goes down after decreasing the bargaining power of workers, but it goes up if

Danninger (2005) who conclude that the first-best reform strategy will be a comprehensive reform package of labor and product market policies, which would require some form of coordination (either sequential, or simultaneous). 


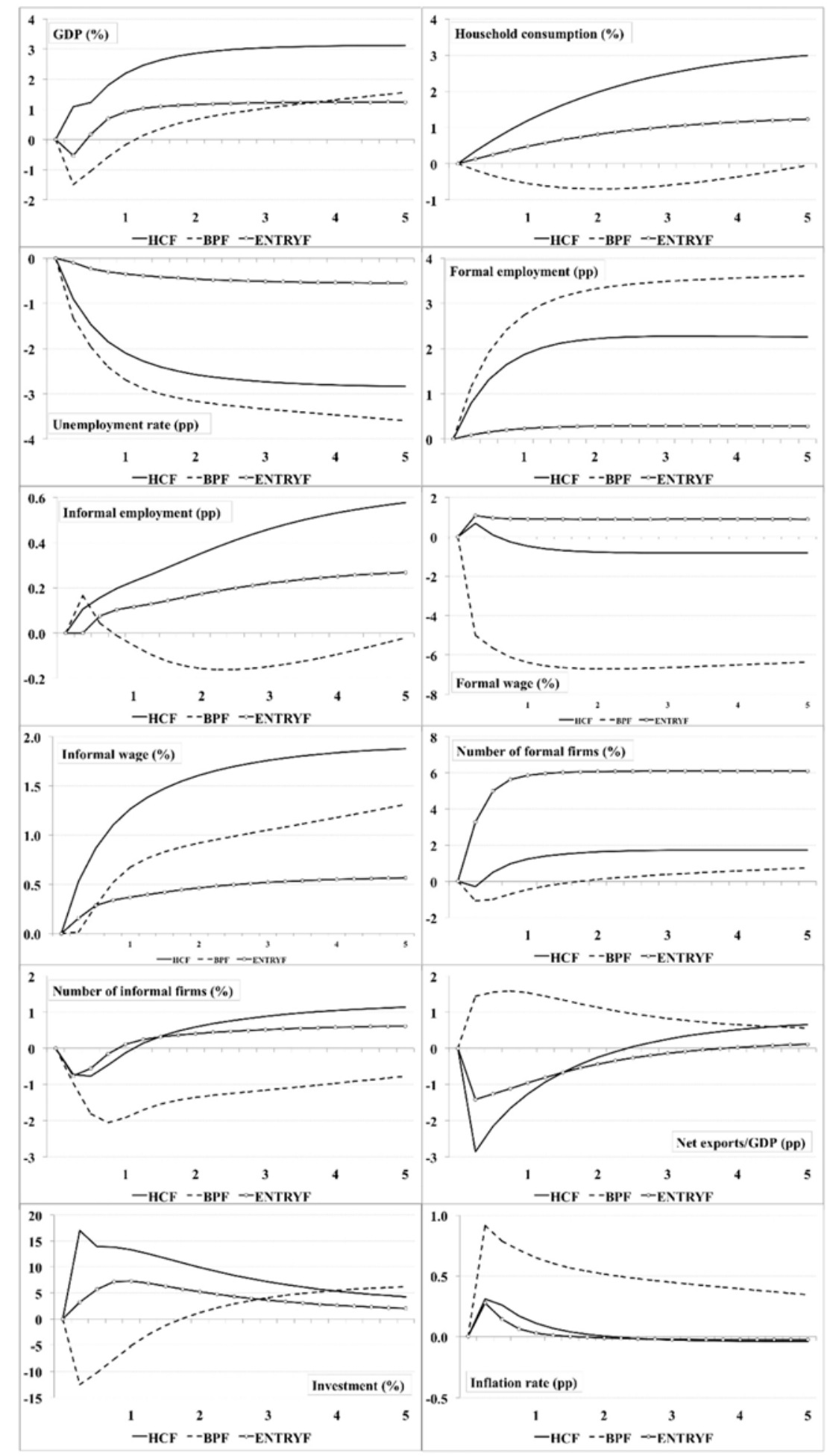

Figure 5: Short-run effects of single labor and product market reforms in South Africa. The chart shows the short-run effects (first 5 years after the shock) of a permanent and unexpected 10 percent decrease in formal hiring cost (HCF), formal bargaining power of workers (BPF), and formal entry cost (ENTRYF). 
the hiring cost is cut down. Furthermore, net exports go up if the bargaining power of workers declines, but they go down if the cost of hiring is reduced. Also, less inflationary pressure accompanies a hiring cost policy, while formal wages decrease more significantly with a decline in workers' bargaining power. The competition response is also different, that is, the number of formal firms goes down first if the bargaining power of workers goes down, but otherwise it stagnates.

The intuition behind the decline or stagnation of output after the shock - in spite of the inevitable long-run gain - is that formal wages decline more in the short term than in the long run following the bargaining power reform, while both labor market reforms imply a smaller increase in informal wages after the shock - compared to a later point in the transition path. Hence, demand starts to increase with a lag, namely, both investment and consumption decline, or increase less at the beginning. Also, it takes some time until new firms enter the market.

As regards reforming the product markets, GDP declines in the first two quarters. Unemployment immediately starts to go down, though less than with a labor market reform. As with the hiring cost policy, not only formal employment, but also unofficial employment go up; however, informal workers are less productive. Although net exports increase in the long run, there is a fall in the short run. Both sectoral wages increase. The number of firms in the informal sector first declines, then starts to rise, while the number of formal firms rises considerably immediately upon policy implementation.

Compared to labor market reforms, the speed of adjustment is larger. In particular, the level of output is already close to the post-reform level one year after the shock (it takes about two to four years to achieve the same with a labor market reform). The reason is that competition in the formal sector increases quite rapidly when the market entry barriers are reduced. In connection with this, wages also quickly adjust. Still, because entering the market takes some time, on the whole, there is a small decline in GDP after the shock (and also because entry costs are financed by the households).

Again, our results do not always coincide with those in the literature. Cacciatore et al. (2016b) claim that short-run costs last longer with a product market reform than with a labor market reform. We find that GDP declines in the first two quarters after a product market reform, but if the bargaining power of workers is lowered, GDP decreases in the first four quarters. Also, there are other costs, such as the decline in household consumption or investment following a decrease in the bargaining power of workers, or a fall in net exports when the entry cost of the hiring cost are lowered. Thus, we can conclude that all reforms entail short-term costs, and the diffusion (how many agents, sectors, etc. are affected), the magnitude, and the duration of these costs are not always greater with one reform than with the other.

\subsection{Reform packages}

Because structural reforms imply short-run costs - the extent varies by agent and by sector -, combining reforms is a potentially useful tool to mitigate overall costs in the short term, at 
least in some cases (Figures 6-9). ${ }^{27}$ The following combinations are explored: (i) a decrease in hiring cost and bargaining power of workers, (ii) a decrease in hiring cost and entry cost, (iii) a decrease in bargaining power of workers and entry cost, and (iv) a combination of all three single policies (all policies are meant in the formal economy).

When mixing the hiring cost policy with the bargaining power of workers policy, output does not decrease during the first year compared to the single bargaining power of workers policy. This is also true for household consumption and investment. At the same time, net exports, formal wages, and the number of firms in the formal sector still go down.

Then, if not only the formal hiring cost, but also the formal entry cost are lowered, one can avoid a decrease in GDP in the short run. In addition, if both the bargaining power of workers and the formal entry cost are decreased, neither household consumption nor net exports fall. Hence, product market deregulation is very successful at reducing short-term costs.

In line with Cacciatore et al. (2016b), we can come to the conclusion that parallel reforms might mitigate short-run costs. Still, joint policies might be costly too, depending on which policies we combine, or which variables we consider. Nevertheless, if there is enough policy space, it seems to be possible to introduce a package of policies, where each policy is carried out in such amount that most of the short-term costs are avoided. ${ }^{28}$

\subsection{Reform sequencing}

If several policies are implemented, sequencing becomes a vital issue. As pointed out by Edwards (1989), Murphy et al. (1992), Dewatripont and Roland (1995), or Hasumann et al. (2005), the success of implementation might depend on the order of reforms. Hausmann et al. (2005) recommends to target the most binding constraints, while Dewatripont and Roland (1995) suggest to prioritize on political feasibility. One stream in the literature, e.g.

Blanchard and Giavazzi (2003) or Kugler and Pica (2004), claim that product market reforms should precede labor market deregulation. Andres et al. (2014) also find that product market reforms Granger cause labor market reforms, however, they claim that the former are not obviously easier, and can lead to tensions if they are not accompanied by greater labor market flexibility. In addition, rent seeking is not the only motivation behind the resistance to changing labor market institutions; for instance, wage rigidity also provides insurance against economy-wide risks (Agell, 1999). In an effort to contribute to this crucial query, we will explore how the choice of reform sequence influences the transition path; with a special interest in the speed of adjustment, which is defined as the pace the country needs to move from the pre-reform to the post-reform equilibria (Figures 10-13).

The first policy package we study is a decrease in both the bargaining power of workers and the hiring cost. If first the hiring cost and afterward the bargaining power of workers is decreased, output goes up faster in the first half of the transition, and then it increases gradually. If the opposite order is chosen, the speed of output convergence is the opposite, too. However, if first the level of unionization is lowered, the formal employment response results in unemployment falling more quickly, and staying at lower levels for a longer time.

\footnotetext{
${ }^{27}$ See also Table A6 in the Appendix. Also, mixing reforms can reinforce the positive impacts of single policies, but here we focus on mitigating the negative effects.

${ }^{28}$ However, we did not examine optimal policies in this paper; we urge further research in this area. As well, an additional issue worth looking at, and we call for further research, is how monetary or fiscal policies can support the implementation of structural reforms.
} 


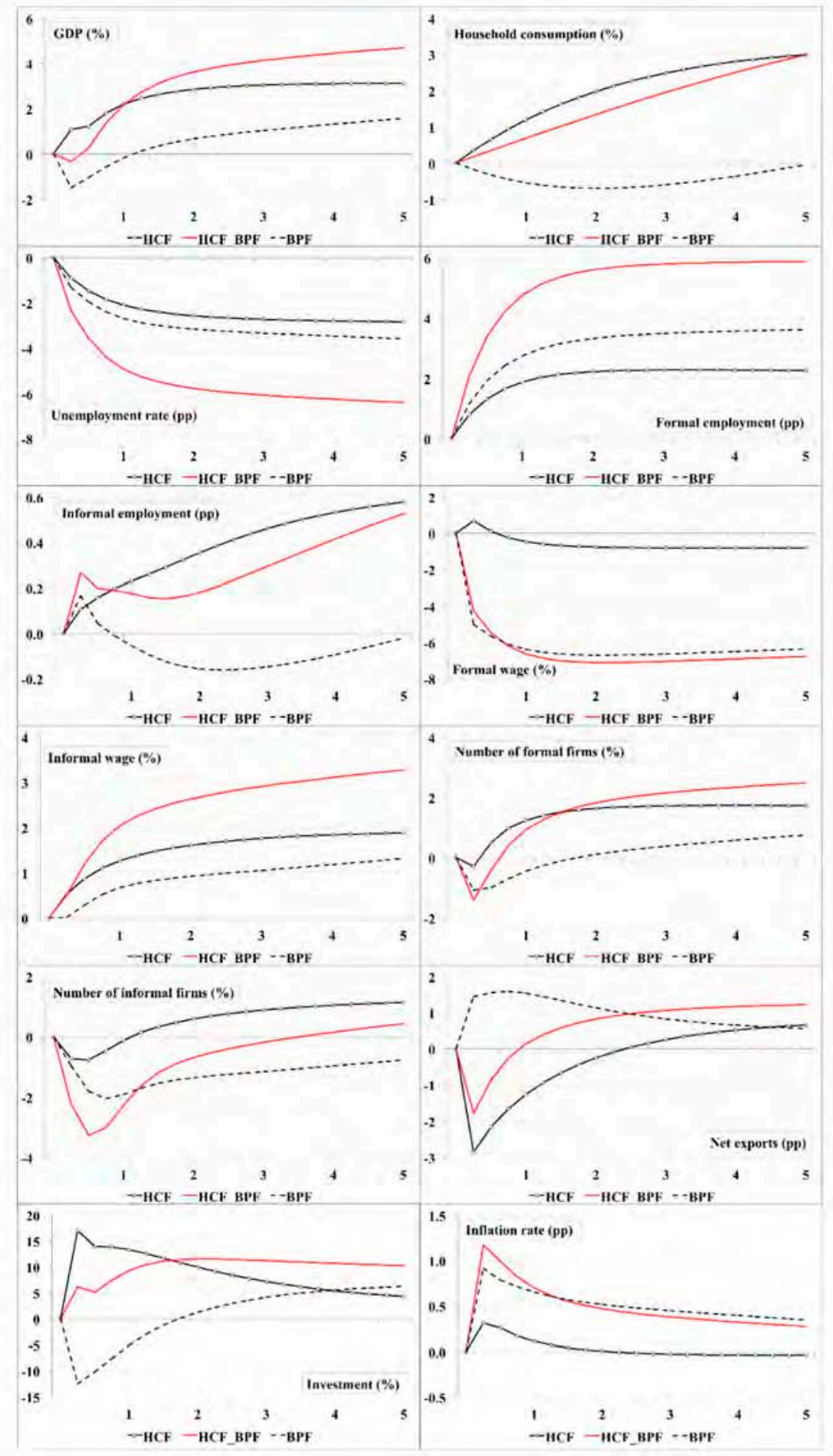

Figure 6: Short-run effects of a combined decrease in formal hiring cost and bargaining power of workers in South Africa. The chart shows the short-run effects (first 5 years after the shock) of a permanent and unexpected 10 percent decrease in formal hiring cost (line with marker), formal bargaining power of workers (dotted black line), and their combination (red line). 


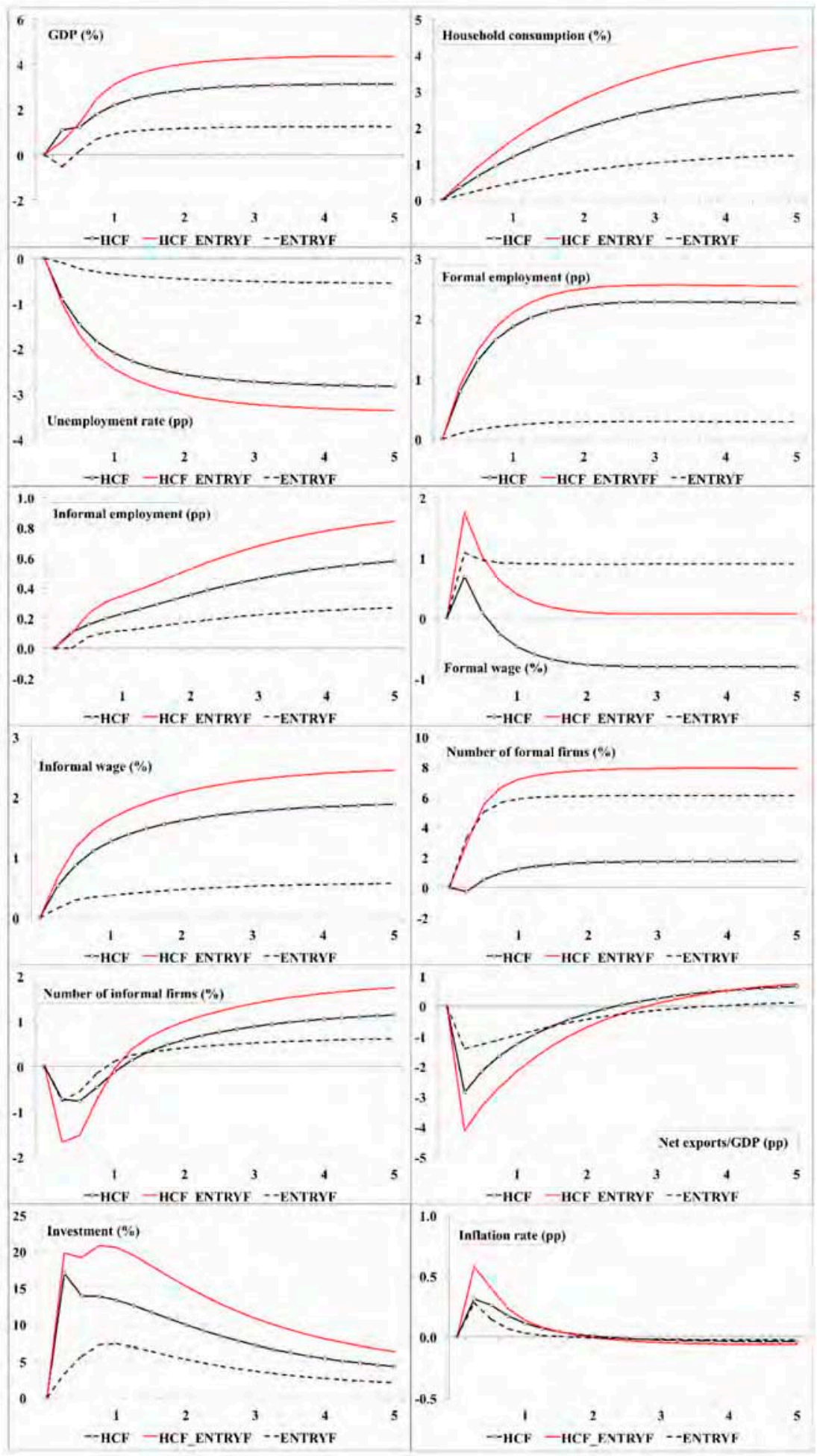

Figure 7: Short-run effects of a combined decrease in formal hiring cost and entry cost in South Africa. The chart shows the short-run effects (first 5 years after the shock) of a permanent and unexpected 10 percent decrease in formal hiring cost (line with marker), formal entry cost (dotted black line), and their combination (red line). 


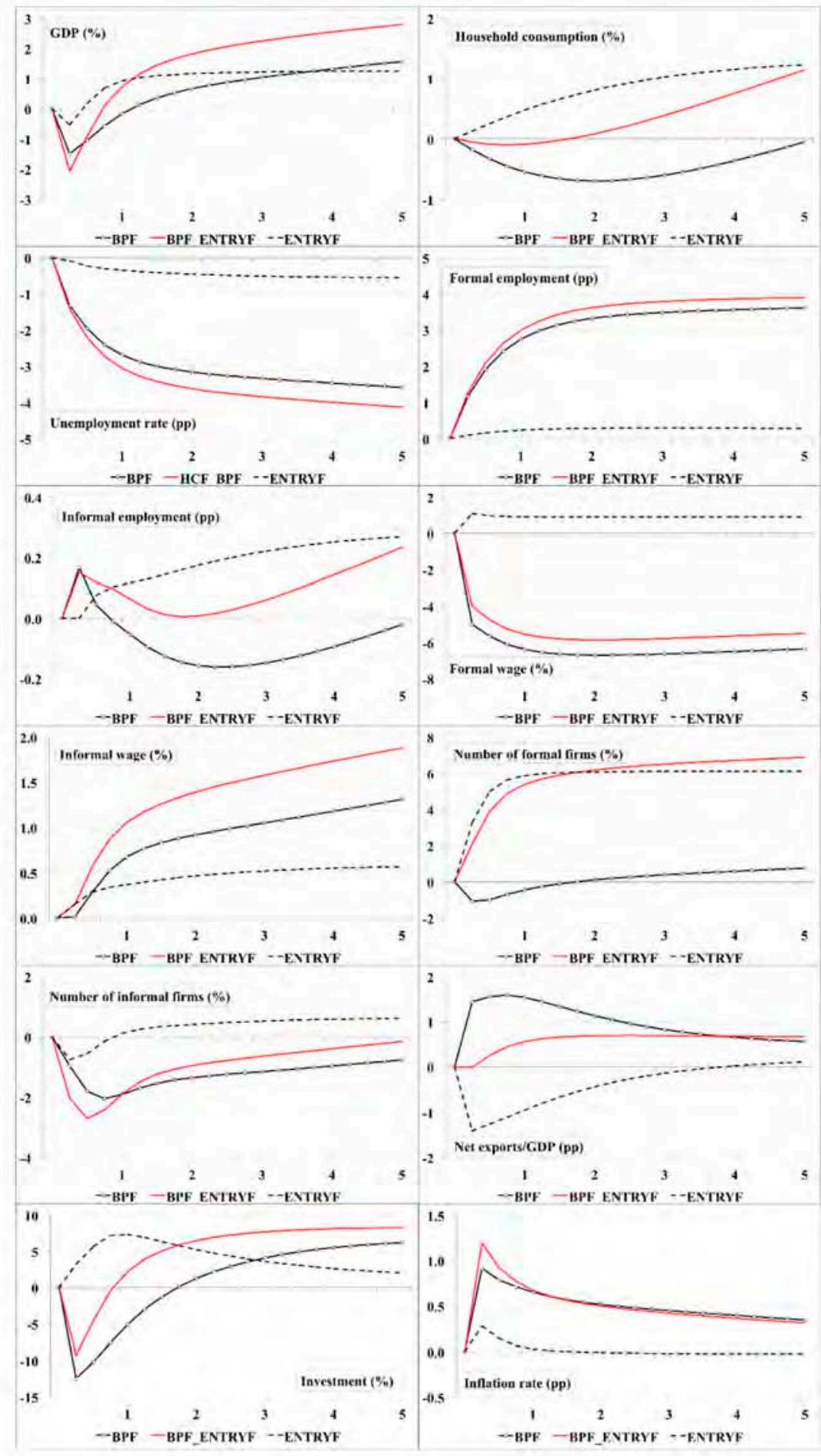

Figure 8: Short-run effects of a combined decrease in formal bargaining power of workers and entry cost in South Africa. The chart shows the short-run effects (first 5 years after the shock) of a permanent and unexpected 10 percent decrease in formal bargaining power of workers (line with marker), formal entry cost (dotted black line), and their combination (red line). 


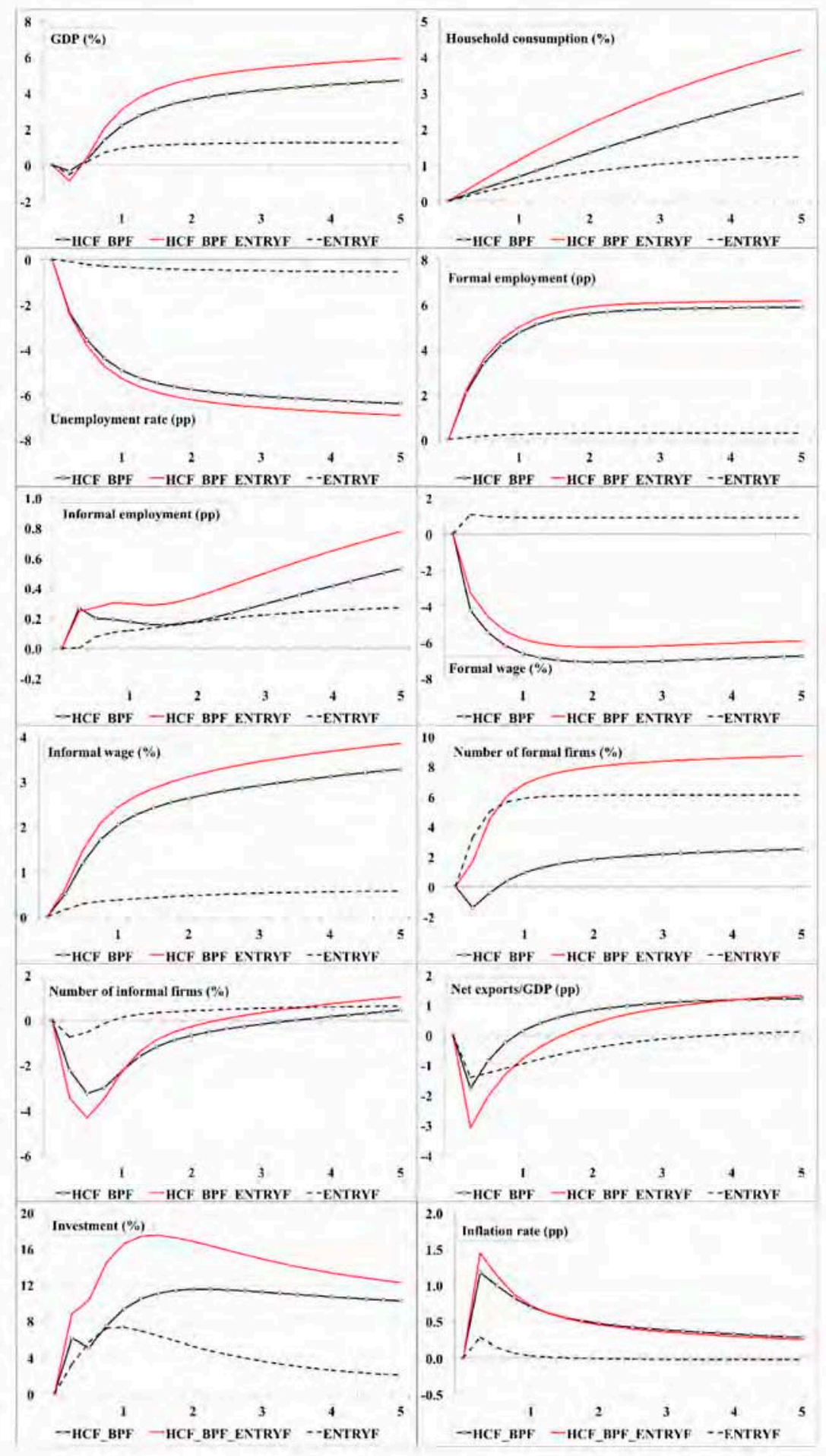

Figure 9: Short-run effects of a combined decrease in formal hiring cost and bargaining power of workers, and entry cost in South Africa. The chart shows the short-run effects (first 5 years after the shock) of a permanent and unexpected 10 percent decrease in formal hiring cost and bargaining power of workers (line with marker), formal entry cost (dotted black line), and their combination (red line). 


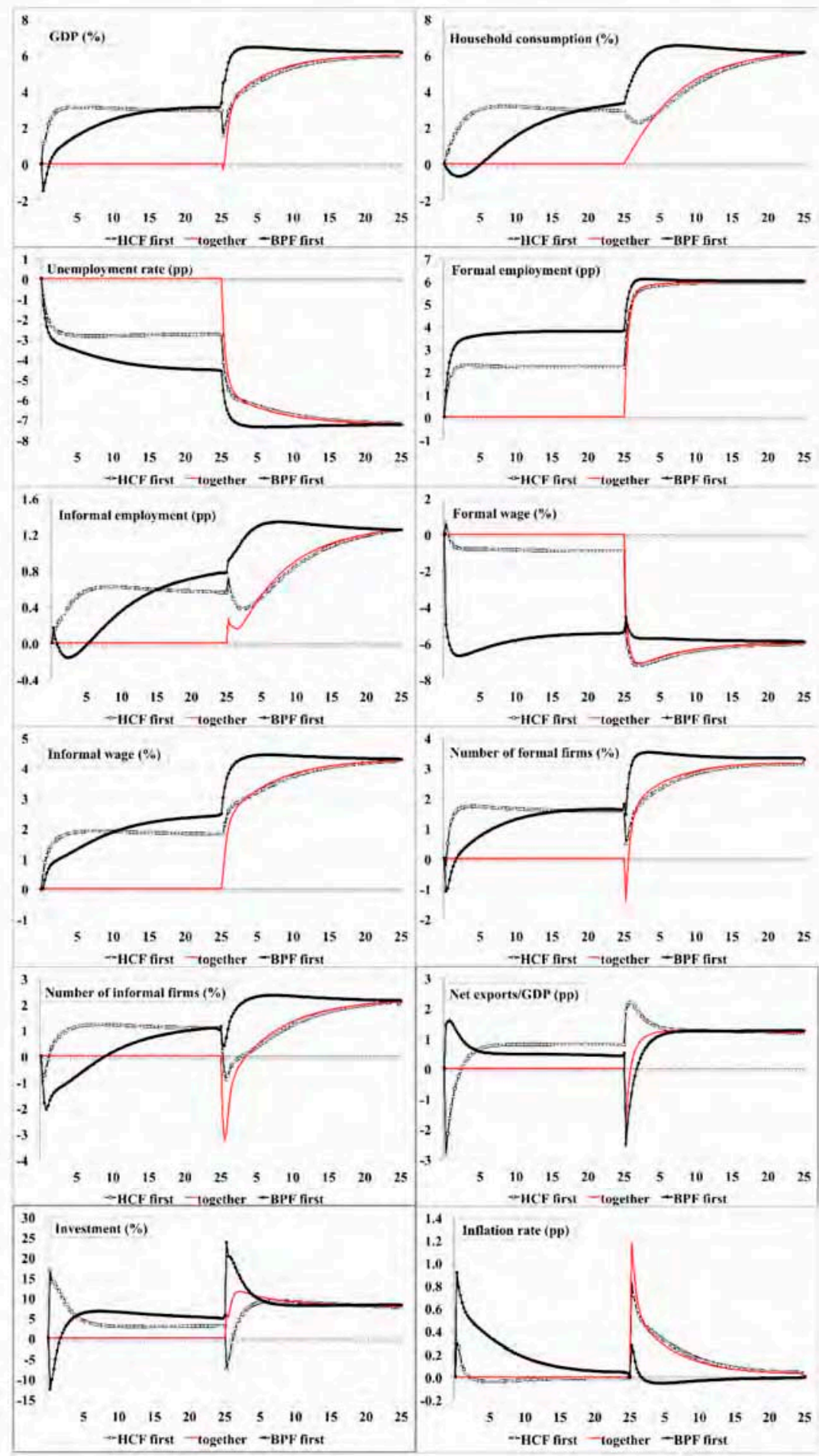

Figure 10: Sequencing of a decrease in formal hiring cost and bargaining power of workers in South Africa. The lines show the long-run ( 25 years +25 years) effects of permanent and unexpected policies of size 10 percent. Line with squared marker: first a decrease in formal hiring cost, then a decrease in formal bargaining power of workers. Line with round marker: the opposite. Red line: both policies are implemented during the second 25 years. 


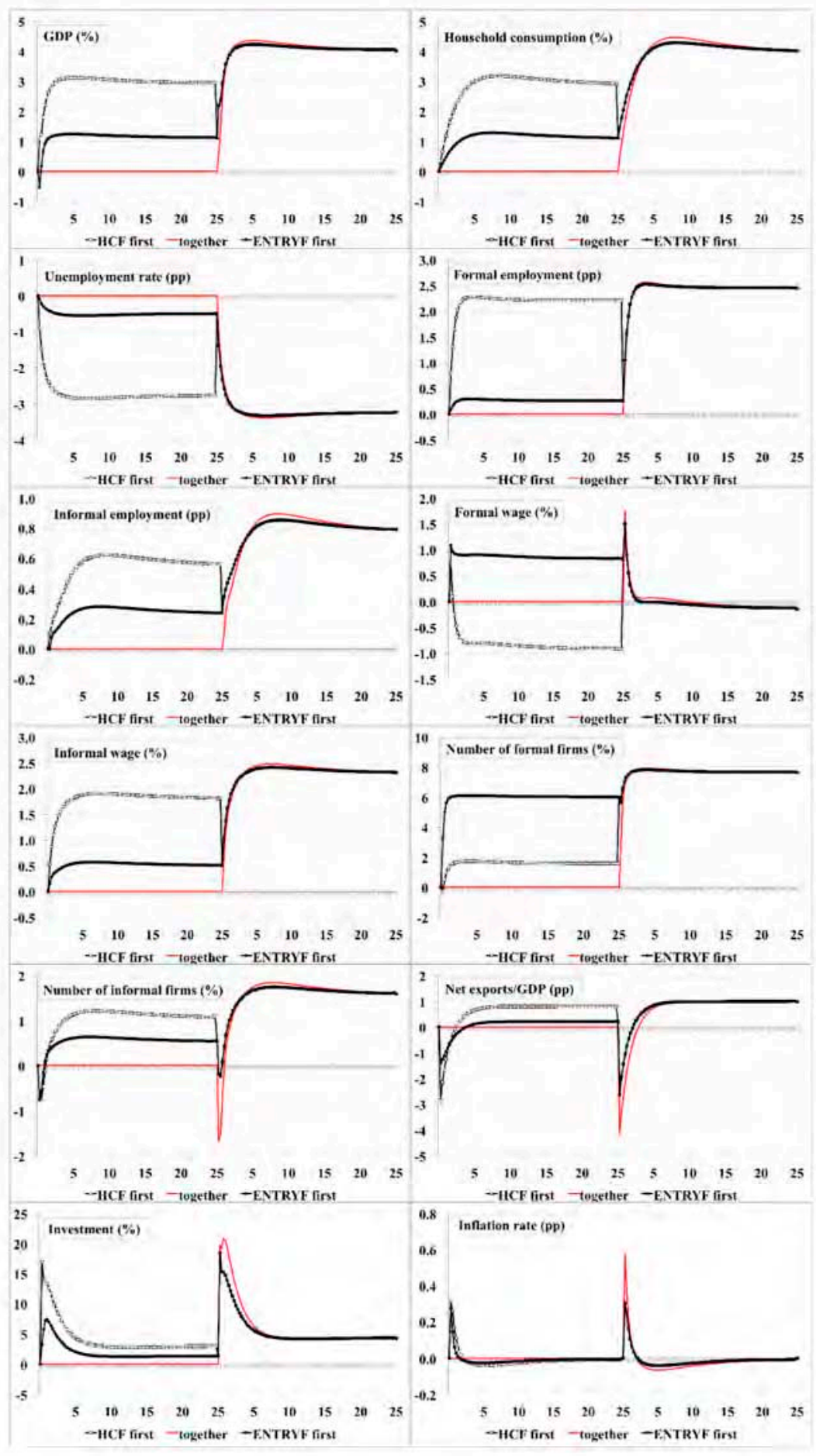

Figure 11: Sequencing of a decrease in formal hiring cost and entry cost in South Africa. The lines show the long-run ( 25 years +25 years) effects of permanent and unexpected policies of size 10 percent. Line with squared marker: first a decrease in formal hiring cost, then a decrease in formal entry cost. Line with round marker: the opposite. Red line: both policies are implemented during the second 25 years. 


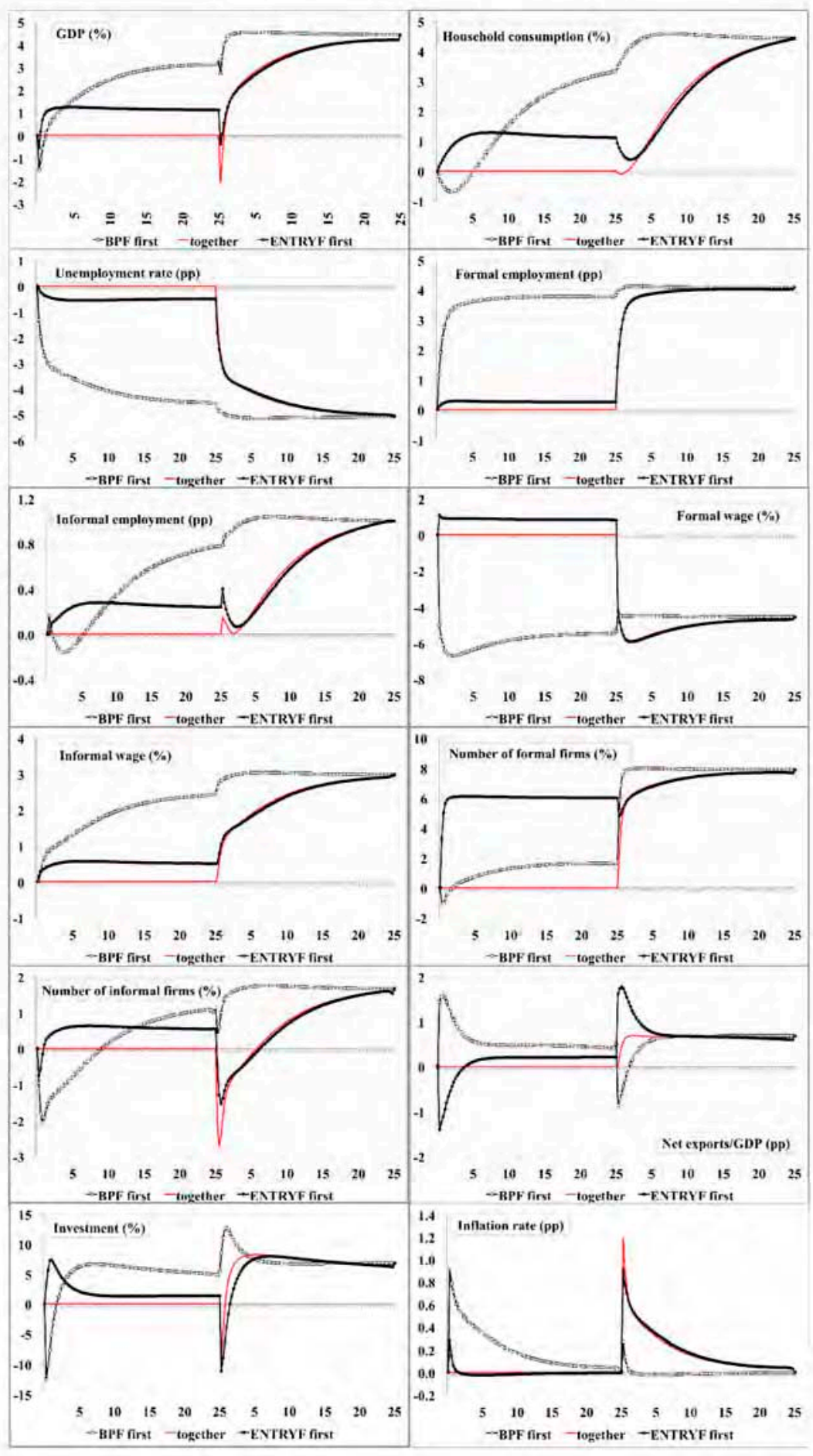

Figure 12: Sequencing of a decrease in formal bargaining power of workers and entry cost in South Africa. The lines show the long-run ( 25 years +25 years) effects of permanent and unexpected policies of size 10 percent. Line with squared marker: first a decrease in formal bargaining power of workers, then a decrease in formal entry cost. Line with round marker: the opposite. Red line: both policies are implemented during the second 25 years. 

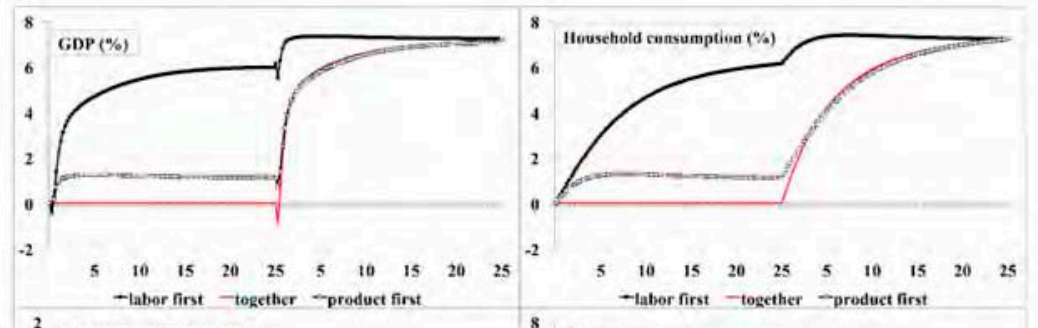

$\begin{array}{llllllllll}5 & 10 & 15 & 20 & 25 & 5 & 10 & 15 & 20 & 25\end{array}$

-laber first - together - product first

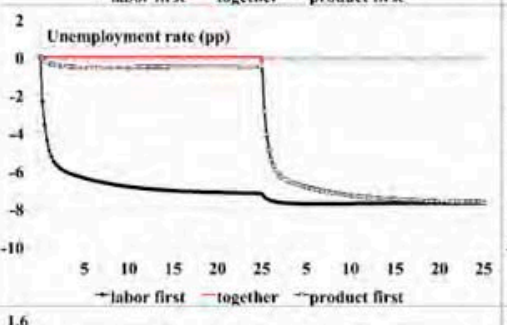

Formal employment (pp)

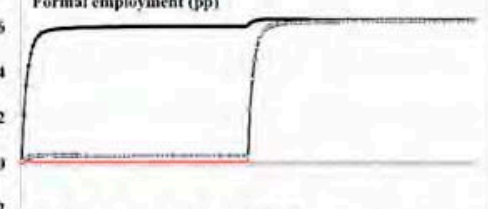

$\rightarrow$ tahor first - together tproduct firs

$\begin{array}{llllllllll}5 & 10 & 15 & 20 & 25 & 5 & 10 & 15 & 20 & 25\end{array}$ -laber first -together - Pproduct first
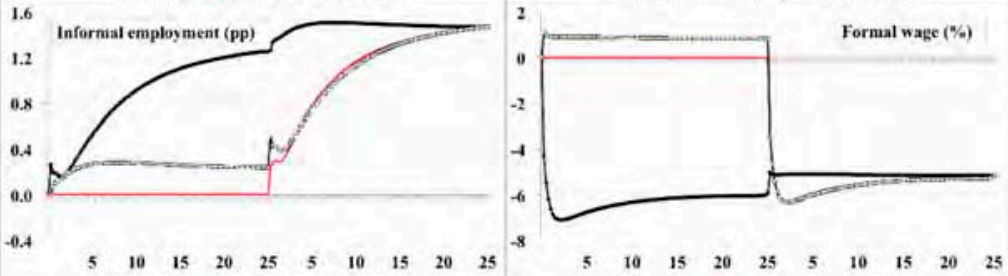

-laber first - together -product first -labor first - Together - product first
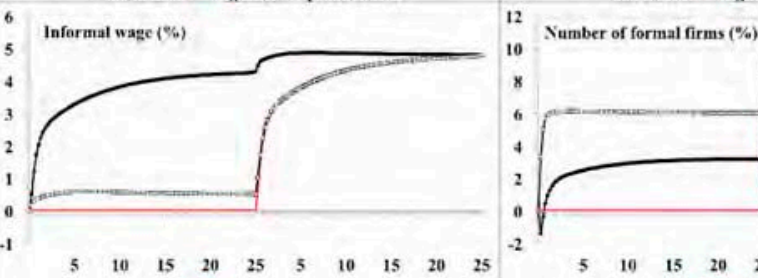

Number of formal firms $(\%$

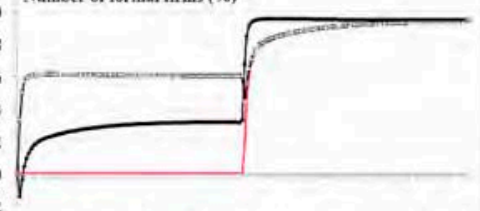

$\begin{array}{llllllllll}5 & 10 & 15 & 20 & 25 & 5 & 10 & 15 & 20 & 25\end{array}$ - labor first -together -product first

-laber first - together - רproduet first

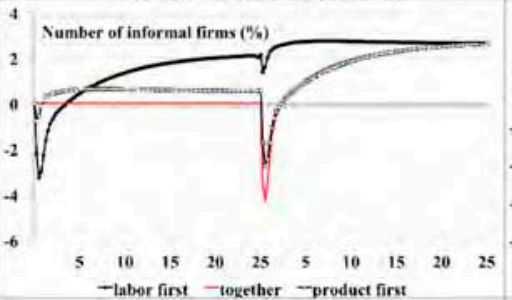

20

- laber first - together -product first
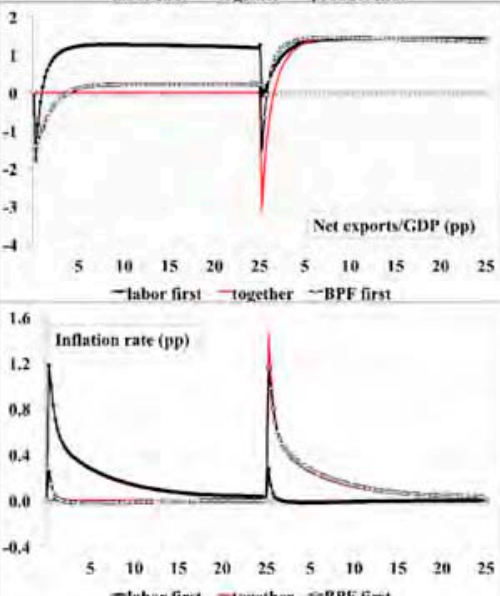

Figure 13: Sequencing of a decrease in formal hiring cost and bargaining power of workers, and entry cost in South Africa. The lines show the long-run ( 25 years +25 years) effects of permanent and unexpected policies of size 10 percent. Line with squared marker: first a decrease in formal hiring cost and bargaining power of workers, then a decrease in formal entry cost. Line with round marker: the opposite. Red line: both policies are implemented during the second 25 years. 
Regarding underground employment, if we start with a workers' bargaining power reform, informal employment is lower in the first half of transition and higher later, compared to starting with the hiring cost policy. Not only the speed of adjustment is affected by sequencing, but sometimes the signs are as well. Particularly, net exports decrease after a decrease in hiring cost, but increase after a decrease in bargaining power of workers. A drawback of the bargaining power policy is, however, that wages in the formal sector quickly decline, and do not recover, while inflation pressure is also higher. Hence, on the whole, no particular labor market policy seems better than the other in this regard.

If a decrease in workers' bargaining power is combined with a decrease in entry cost, not only for unemployment, but also for output it is better to start with the bargaining power policy. Under these circumstances, output goes up faster and stays at high levels, while unemployment goes down faster and stays at low levels; once again, the latter can be explained mainly by the reaction of formal employment. As with the hiring cost policy, net exports decrease with a product market reform, while they increase otherwise. However, starting with a bargaining power policy seems to be more controversial; formal wages quickly and permanently decline, while informal wages soar. Regarding product market competition, to induce a considerable increase in the number of firms, the entry cost must be cut.

Similarly, as regards a combination of lowering hiring and entry costs, it seems to be more efficient to start with the hiring cost policy, because GDP immediately and permanently increases, while unemployment decreases accordingly. Now, the latter effect is due not only to the reaction of formal employment, but is related as well to the response of unofficial employment. Net exports fall regardless of policy-implementation sequence, although they decrease less after a product market reform. As regards wages, formal wages increase after the product market reform, but they go down if the hiring cost is lowered; informal wages always increase. Again, a product market reform is more successful than a labor market reform in increasing market competition.

Finally, if all three policies are mixed, and we start with the labor market reform, output rises faster, and remains at higher levels during most of the transition. Also, unemployment falls more quickly and steadily. Regarding net exports, there is always a decrease, but the recovery is quicker. A drawback, however, is that formal wages decline; also competition in the formal economy increases more with a product market reform.

Generally, we do not concur with those who claim that it is better to start with a product market reform. For instance, Blanchard and Giavazzi (2003) make this conclusion because they find that a product market reform increases, while a labor market reform decreases wages. ${ }^{29}$ On the one hand, if informality is considered, this claim is only true for formal wages; informal wages always go up if the product or labor markets are deregulated. On the other hand, short-run costs do not only emerge in connection with wages (output, consumption, net exports are also affected), in addition, the total wage bill might be relevant to look at as well (because it does not only take the wage reaction into account, but that of employment). Last, there are political economy constraints which matter for implementation; a favorable outcome that materializes sooner might help in this regard. Concerning output, unemployment and several other aspects of the macroeconomy - with the exception of market

\footnotetext{
${ }^{29}$ They investigate a lower markup, a reduction in entry costs, and a reduction in the bargaining power of workers.
} 
competition and formal wages - beginning with a product market reform typically results in a later starting point in the transition, output remains at a lower and unemployment at a higher level for a longer amount of time. Hence, we can conclude that it is often better to start with a labor market reform than with a product market reform, especially concerning the speed of adjustment. $^{30}$

\section{Conclusion}

In this paper we took up the topic of structural reforms, and investigated their macroeconomic impact, in particular on output and employment, in a framework where the main innovation was the incorporation of a shadow economy into an open-economy dynamic general equilibrium model. Both the long-run effects and the transition towards the postreform equilibrium were examined. First, single policies were investigated, then the focus moved towards joint reforms and sequencing. South Africa, an emerging country was considered as an example.

We concluded that the informal economy is a crucial determinant of the sign, and, in particular, the magnitude of the macroeconomic effect of labor and product market deregulation policies. Also, in the long run, both labor and product market reforms considerably increased output, although labor market reforms were more successful in decreasing unemployment. Then, while the level of underground employment did not decrease in the long run, its share in total employment did. Nevertheless, several short-term costs were identified, for example a decrease in household consumption, investment, net exports or output, or a decrease in competition. These short-run costs accompanied all single reforms, although to a different extent. Combining reforms often mitigated them, especially when one of the reforms was carried out in the goods markets. Finally, we found that - except for formal wages and market competition - it was usually better to start with a labor market reform than with a product market reform, in particular concerning the speed of adjustment which we find crucial for reform implementation.

Nevertheless, we urge further research in this area, particularly, on optimal structural reform packages and sequencing, and on other - monetary and fiscal - policies which could support implementation.

\footnotetext{
${ }^{30}$ Again, we did not investigate optimal sequencing, further research should be carried out in this regard. Similarly, and we call for more research as well, monetary or fiscal policies could support the implementation of structural reforms, by mitigating short-term costs of reforms.
} 


\section{Appendix}

\section{A Definition, measurement and role of shadow economy}

Because shadow output and employment are, by definition, in the shadow, it is not straightforward to define or measure them.

Concerning output, the broad definitions usually incorporate all monetary and non-monetary transactions, and all legal and illegal activities (Table A1). Hence, not only tax evasion or tax avoidance, but also, for example, drugs and prostitution are included. In a narrow approach, however, informality is mostly related to avoiding taxation or legal requirements. As Schneider (2012, page 6) claims: “The shadow economy includes all market-based legal production of goods and services that are deliberately concealed from public authorities for the following reasons: 1 . to avoid payment of income, value added or other taxes, 2 . to avoid payment of social security contributions, 3 . to avoid having to meet certain legal labor market standards, such as minimum wages, maximum working hours, safety standards, etc., and 4. to avoid complying with certain administrative obligations, such as completing statistical questionnaires or other administrative forms." Regarding employment, the "shadow labor market includes all cases, where the employees or the employers, or both, occupy a shadow economy position" (Schneider, 2012, page 28).

\begin{tabular}{|c|c|c|c|c|}
\hline \multirow{3}{*}{$\begin{array}{l}\text { Illegal } \\
\text { Activities }\end{array}$} & \multicolumn{2}{|c|}{ Monetary Transactions } & \multicolumn{2}{|c|}{$\begin{array}{l}\text { Non-Monetary } \\
\text { Transactions }\end{array}$} \\
\hline & \multicolumn{2}{|c|}{$\begin{array}{l}\text { Trade in stolen goods, } \\
\text { drugs; manufacture of } \\
\text { drugs; prostitution, } \\
\text { gambling, fraud }\end{array}$} & $\begin{array}{l}\text { Barter, drugs, } \\
\text { stolen goods, } \\
\text { etc. }\end{array}$ & $\begin{array}{l}\text { Produce or } \\
\text { grow drugs } \\
\text { for own use. } \\
\text { Theft for } \\
\text { own use. }\end{array}$ \\
\hline & $\begin{array}{c}\text { Tax } \\
\text { Evasion }\end{array}$ & $\begin{array}{c}\text { Tax } \\
\text { Avoidance }\end{array}$ & $\begin{array}{c}\text { Tax } \\
\text { Evasion }\end{array}$ & $\begin{array}{c}\text { Tax } \\
\text { Avoidance }\end{array}$ \\
\hline $\begin{array}{l}\text { Legal } \\
\text { Activities }\end{array}$ & $\begin{array}{l}\text { Unreported } \\
\text { income from } \\
\text { self-employ- } \\
\text { ment, } \\
\text { wages, } \\
\text { salaries, and } \\
\text { assets }\end{array}$ & $\begin{array}{l}\text { Employee } \\
\text { discounts, } \\
\text { fringe } \\
\text { benefits } \\
\text { (cars, } \\
\text { subsidized } \\
\text { food, etc.) }\end{array}$ & $\begin{array}{l}\text { Barter of legal } \\
\text { services and } \\
\text { goods. }\end{array}$ & $\begin{array}{l}\text { Do-it- } \\
\text { yourself } \\
\text { work }\end{array}$ \\
\hline
\end{tabular}

Table A1: A taxonomy of underground economic activities (broad concept). Source is Mirus and Smith (1977, page 5).

As regards estimation methodologies, Schneider and Enste (2000) point out that the most common ones are the currency demand method (the size of shadow economy is equal to the unexplained increase in currency demand), and the MIMIC method (which is a factor model). Nevertheless, they also provide detailed descriptions on other approaches. 


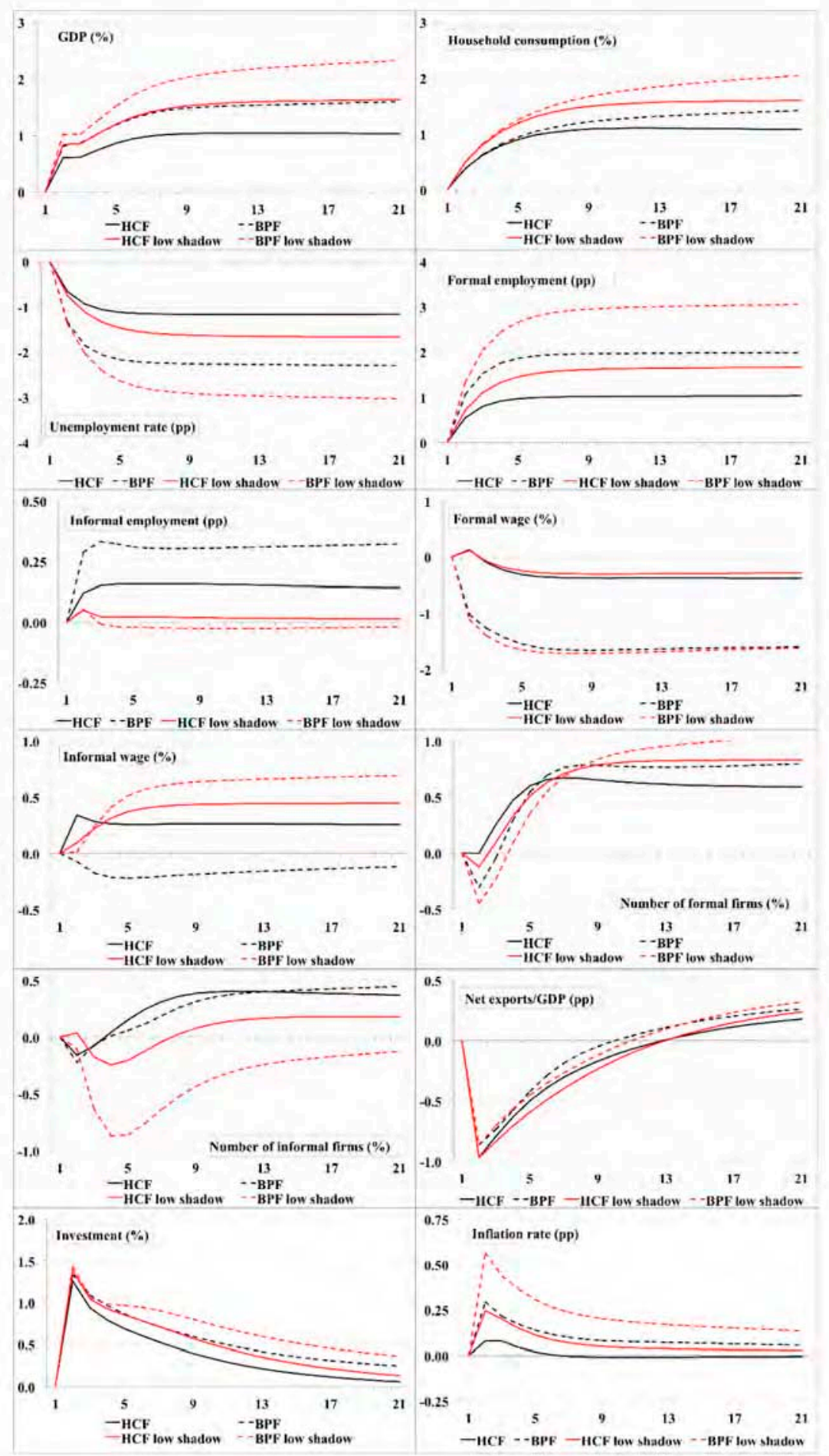

Figure A1: The role of shadow economy in short-run effects of a decrease in formal hiring cost and barganing power of workers. The chart shows the short-run effects (first 5 years after the shock) of a permanent and unexpected 10 percent decrease in formal hiring cost and bargaining power of workers. Low informality (red lines) means that the size of shadow economy in output is $1 / 3$ of the original value. 


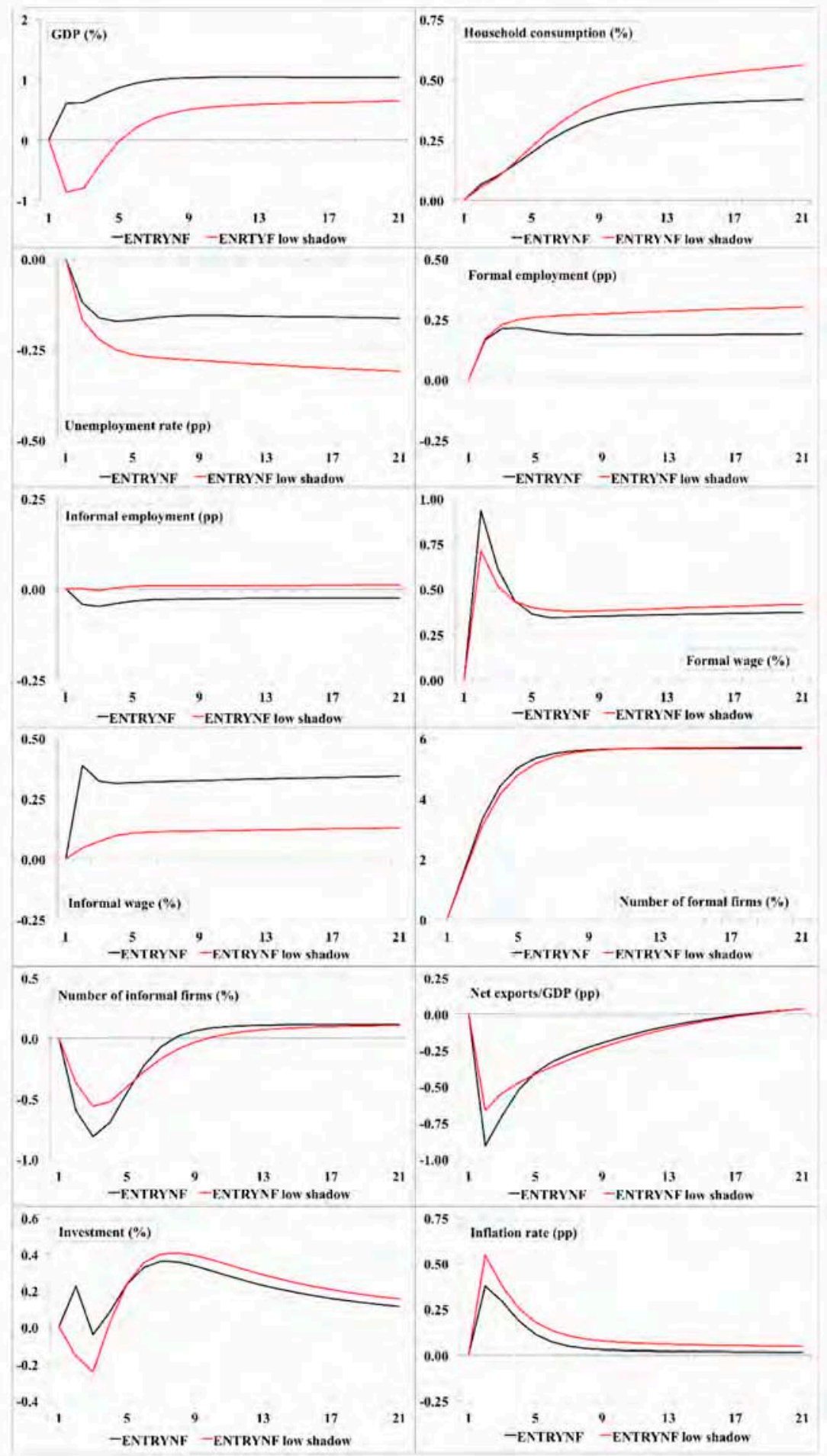

Figure A2: The role of shadow economy in short-run effects of a decrease in formal entry cost. The chart shows the short-run effects (first 5 years after the shock) of a permanent and unexpected 10 percent decrease in formal entry cost. Low informality (red line) means that the size of shadow economy in output is $1 / 3$ of the original value. 


\begin{tabular}{|c|c|c|c|c|}
\hline $\begin{array}{c}\text { Name of } \\
\text { fixed or parametrized parameter or variable }\end{array}$ & Sign of & Baseline & Alternative 1 & Alternative 2 \\
\hline Discount factor & $\beta$ & 0.99 & & \\
\hline Physical capital depreciation rate & $\delta$ & 0.02 & & \\
\hline Formal capital income share & $\psi_{\mathrm{F}}$ & 0.3 & & \\
\hline Informal capital income share & $\psi_{1}$ & 0.2 & & \\
\hline Markup in formal sector (\%) & $\varepsilon_{\mathrm{F}}$ & 10 & & \\
\hline Markup in informal sector (\%) & $\varepsilon_{1}$ & 10 & & \\
\hline Formal productivity level & $\theta_{\mathrm{F}}$ & 1 & & \\
\hline Informal productivity level & $\theta_{1}$ & 1 & & \\
\hline Formality bias & $\mu_{\mathrm{F}}$ & 0.4 & 0.8 & \\
\hline Home inflation $(\%, Q \circ Q)$ & $\pi$ & 1 & & \\
\hline Exchange rate depreciation rate $(\%, Q \circ Q)$ & & 0.5 & & - \\
\hline Exit rate of formal retailers & $\delta_{\mathrm{F}}$ & 0.05 & & \\
\hline Exit rate of informal retailers & $\delta_{1}$ & 0.15 & & \\
\hline $\begin{array}{l}\text { Household consumption expenditure to GDP ratio } \\
\text { (\%) }\end{array}$ & & 70 & & \\
\hline $\begin{array}{l}\text { Government consumption expenditure to GDP ratio } \\
(\%)\end{array}$ & & 20 & & \\
\hline Exports to GDP ratio (\%) & $\alpha_{x}$ & 40 & & 0 \\
\hline Public social protection to GDP ratio (\%) & & 5 & & \\
\hline Firing probability in the formal sector & probf $_{\mathrm{F}}$ & 0.1 & & \\
\hline Firing probability in the informal sector & probf $_{1}$ & 0.15 & 0.9 & \\
\hline Ratio of hiring cost in wage in formal sector & & 0.5 & & \\
\hline Ratio of hiring cost in wage in informal sector & & 0.5 & & \\
\hline $\begin{array}{l}\text { Elasticity of substitution between home and foreign } \\
\text { goods }\end{array}$ & $\mu$ & 0.7 & & - \\
\hline Home bias & $\alpha$ & 0.7 & & 1 \\
\hline Export price elasticity & $\varsigma_{\mathrm{x}}$ & 3 & & - \\
\hline Share of income tax revenue in GDP (\%) & $\tau_{\mathrm{F}}$ & 10 & & \\
\hline Exchange rate pass-through to import prices & $\varsigma_{\mathrm{M}}$ & 0.7 & & - \\
\hline $\begin{array}{l}\text { Entry cost in the formal sector (in months of } \\
\text { production) }\end{array}$ & & 0.67 & & \\
\hline $\begin{array}{l}\text { Entry cost in the informal sector (in months of } \\
\text { production) }\end{array}$ & & 0.67 & & \\
\hline Share of home production in average wage (\%) & & 5 & & \\
\hline $\begin{array}{l}\text { Elasticity of hiring cost wrt to hiring probability } \\
\text { (formal) }\end{array}$ & $\alpha_{\text {HCF }}$ & 0.5 & & \\
\hline $\begin{array}{l}\text { Elasticity of hiring cost wrt to hiring probability } \\
\text { (informal) }\end{array}$ & $\alpha_{\mathrm{HCI}}$ & 0.5 & & \\
\hline $\begin{array}{l}\text { Elasticity of substitution between formal and } \\
\text { informal goods }\end{array}$ & $\eta$ & 2 & & \\
\hline Formal bargaining power of workers & $\lambda_{\mathrm{F}}$ & 0.6 & & \\
\hline Informal bargaining power of workers & $\lambda_{1}$ & 0.25 & & \\
\hline
\end{tabular}

Table A2: Steady-state parameters of the parametrized economies 


\begin{tabular}{c|l|c}
\hline \multicolumn{3}{c}{ Dynamic parameters } \\
\hline $\mathrm{h}$ & consumption habit & 0.7 \\
$\gamma_{\mathrm{i}}$ & interest rate smoothing & 0.5 \\
$\gamma_{\pi}$ & inflation response & 3 \\
$\gamma_{\mathrm{Y}}$ & output response & 0.5 \\
$\mathrm{dF}$ & formal Rotemberg cost & 5 \\
$\mathrm{dI}$ & informal Rotemberg cost & 5 \\
$\chi$ & interest rate premium & 0.002 \\
$\zeta$ & investment adjustment cost & 2
\end{tabular}

Table A3: Dynamic parameters of the parametrized economies

\section{B Bayesian estimation}
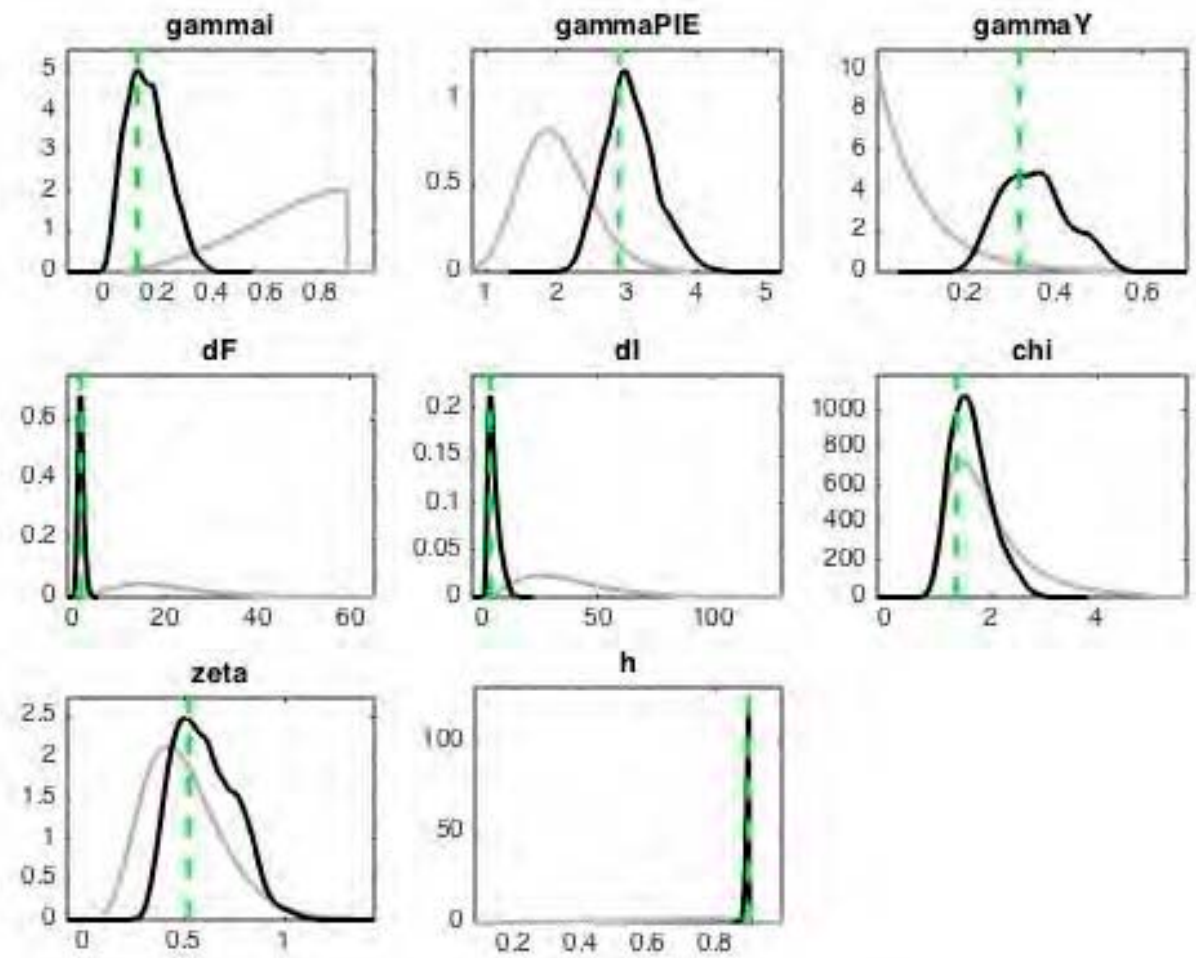

Figure A3: Prior and posterior distributions of structural parameters based on Bayesian estimation using South African data. The parameters are (in order): interest rate smoothing, inflation and output weights in Taylor rule, formal and informal Rotemberg price rigidity costs, interest rate premium, investment adjustment cost and consumption habit. 


\begin{tabular}{|c|c|c|c|c|c|c|}
\hline \multirow[b]{2}{*}{ Shock autocorrelations } & \multirow[b]{2}{*}{ distribution } & \multicolumn{2}{|c|}{ prior } & \multicolumn{3}{|c|}{ posterior } \\
\hline & & mean & $\begin{array}{l}\text { standard } \\
\text { deviation }\end{array}$ & mean & confide & nterval \\
\hline$\rho_{\theta \mathrm{F}}$ formal productivity & beta & 0.8 & 0.2 & 0.15 & 0.05 & 0.25 \\
\hline$\rho_{\theta \mathrm{I}}$ informal productivity & beta & 0.8 & 0.2 & 0.89 & 0.88 & 0.90 \\
\hline$\rho_{\mathrm{tF}}$ income tax & beta & 0.8 & 0.2 & 0.71 & 0.47 & 0.90 \\
\hline$\rho_{\mathrm{w} u}$ social benefit & beta & 0.8 & 0.2 & 0.69 & 0.42 & 0.90 \\
\hline$\rho_{\mathrm{G}}$ government consumption & beta & 0.8 & 0.2 & 0.82 & 0.73 & 0.90 \\
\hline$\rho_{\zeta c}$ preference & beta & 0.8 & 0.2 & 0.80 & 0.67 & 0.90 \\
\hline$\rho_{\beta \mathrm{HCF}}$ formal hiring cost & beta & 0.8 & 0.2 & 0.45 & 0.31 & 0.58 \\
\hline$\rho_{\beta \mathrm{HCl}}$ informal hiring cost & beta & 0.8 & 0.2 & 0.49 & 0.14 & 0.86 \\
\hline$\rho_{\text {probff }}$ formal firing probability & beta & 0.8 & 0.2 & 0.81 & 0.74 & 0.90 \\
\hline$\rho_{\text {probn }}$ informal firing probability & beta & 0.8 & 0.2 & 0.84 & 0.74 & 0.90 \\
\hline$\rho_{\lambda F}$ formal bargaining power & beta & 0.8 & 0.2 & 0.09 & 0.01 & 0.16 \\
\hline$\rho_{\lambda \Lambda}$ informal bargaining power & beta & 0.8 & 0.2 & 0.51 & 0.20 & 0.89 \\
\hline$\rho_{\text {entryf }}$ formal entry cost & beta & 0.8 & 0.2 & 0.85 & 0.81 & 0.90 \\
\hline$\rho_{\text {entryl }}$ informal entry cost & beta & 0.8 & 0.2 & 0.80 & 0.68 & 0.90 \\
\hline$\rho_{\pi^{*}}$ foreign inflation & beta & 0.8 & 0.2 & 0.24 & 0.12 & 0.35 \\
\hline$\rho_{\mathrm{i}} *$ foreign interest rate & beta & 0.8 & 0.2 & 0.74 & 0.50 & 0.90 \\
\hline
\end{tabular}

Table A4: Prior and posterior distributions of autocorrelations of shocks based on Bayesian estimation using South African data. All priors are maximized to 0.9.

\begin{tabular}{l|c|c|c|c|cc}
\hline \multirow{2}{*}{ Shock standard deviations } & distribution & \multicolumn{2}{|c|}{ prior } & \multicolumn{3}{c}{ posterior } \\
\cline { 3 - 6 } & & mean & $\begin{array}{c}\text { standard } \\
\text { deviation }\end{array}$ & mean & confidence interval \\
\hline$\varepsilon_{\theta \mathrm{F}}$ formal productivity & inverse gamma & 0.2 & 0.1 & 0.43 & 0.36 & 0.49 \\
$\varepsilon_{\theta \mathrm{I}}$ informal productivity & inverse gamma & 0.2 & 0.1 & 0.15 & 0.12 & 0.18 \\
$\varepsilon_{\mathrm{rF}}$ income tax & inverse gamma & 0.2 & 0.1 & 0.27 & 0.08 & 0.54 \\
$\varepsilon_{\mathrm{WU}}$ social benefit & inverse gamma & 0.2 & 0.1 & 0.13 & 0.09 & 0.18 \\
$\varepsilon_{\mathrm{G}}$ government consumption & inverse gamma & 0.2 & 0.1 & 0.07 & 0.06 & 0.08 \\
$\varepsilon_{\zeta \mathrm{c}}$ preference & inverse gamma & 0.2 & 0.1 & 0.08 & 0.07 & 0.10 \\
$\varepsilon_{\beta \mathrm{HCF}}$ formal hiring cost & inverse gamma & 0.2 & 0.1 & 0.53 & 0.43 & 0.62 \\
$\varepsilon_{\beta \mathrm{HCI}}$ informal hiring cost & inverse gamma & 0.2 & 0.1 & 0.10 & 0.07 & 0.13 \\
$\varepsilon_{\text {probf }}$ formal firing probability & inverse gamma & 0.2 & 0.1 & 0.32 & 0.19 & 0.44 \\
$\varepsilon_{\text {probf }}$ informal firing probability & inverse gamma & 0.2 & 0.1 & 0.17 & 0.09 & 0.24 \\
$\varepsilon_{\mathrm{\lambda F}}$ formal bargaining power & inverse gamma & 0.2 & 0.1 & 0.17 & 0.14 & 0.20 \\
$\varepsilon_{\lambda \mathrm{II}}$ informal bargaining power & inverse gamma & 0.2 & 0.1 & 0.10 & 0.07 & 0.13 \\
$\varepsilon_{\mathrm{entryF}}$ formal entry cost & inverse gamma & 0.2 & 0.1 & 0.79 & 0.59 & 1.01 \\
$\varepsilon_{\mathrm{entryl}}$ informal entry cost & inverse gamma & 0.2 & 0.1 & 0.16 & 0.08 & 0.23 \\
$\varepsilon_{\mathrm{i} *}$ foreign interest rate & inverse gamma & 0.2 & 0.1 & 0.08 & 0.06 & 0.10 \\
$\varepsilon_{\pi^{*}}$ foreign inflation & inverse gamma & 0.2 & 0.1 & 0.26 & 0.12 & 0.38 \\
$\varepsilon_{\mathrm{i}}$ monetary policy & inverse gamma & 0.2 & 0.1 & 0.07 & 0.06 & 0.09
\end{tabular}

Table A5: Prior and posterior distributions of standard deviations of shocks based on Bayesian estimation using South African data 


\section{Reform packages}

\begin{tabular}{|c|c|c|c|c|c|}
\hline $\begin{array}{l}\text { Long-run effects when } \\
\text { lowering the ... }\end{array}$ & GDP, $\%$ & $\begin{array}{l}\text { Unemployment, } \\
\text { \%point }\end{array}$ & $\begin{array}{c}\text { Formal } \\
\text { employment, } \\
\text { \%point }\end{array}$ & $\begin{array}{c}\text { Informal } \\
\text { employment, } \\
\text { \%point }\end{array}$ & $\begin{array}{r}\text { Formal } \\
\text { wage, \% }\end{array}$ \\
\hline $\begin{array}{l}\text { hiring cost and bargaining } \\
\text { power of workers }\end{array}$ & 6.1 & -7.2 & 6.0 & 1.2 & -5.9 \\
\hline hiring cost and entry cost & 4.0 & -3.2 & 2.4 & 0.8 & -0.1 \\
\hline $\begin{array}{l}\text { bargaining power of workers } \\
\text { and entry cost }\end{array}$ & 4.4 & -5.1 & 4.1 & 1.0 & -4.6 \\
\hline $\begin{array}{l}\text { hiring cost, bargaining power } \\
\text { of workers and entry cost }\end{array}$ & 7.2 & -7.7 & 6.2 & 1.5 & -5.2 \\
\hline $\begin{array}{l}\text { Long-run effects when } \\
\text { lowering the ... }\end{array}$ & $\begin{array}{l}\text { Informal } \\
\text { wage, \% }\end{array}$ & $\begin{array}{c}\text { Number of } \\
\text { formal firms, } \%\end{array}$ & $\begin{array}{l}\text { Number of } \\
\text { informal } \\
\text { firms, \% }\end{array}$ & $\begin{array}{l}\text { Net exports, } \\
\text { \%point }\end{array}$ & $\begin{array}{c}\text { Investment, } \\
\%\end{array}$ \\
\hline $\begin{array}{l}\text { hiring cost and bargaining } \\
\text { power of workers }\end{array}$ & 4.3 & 3.3 & 2.1 & 1.2 & 8.1 \\
\hline hiring cost and entry cost & 2.3 & 7.6 & 1.6 & 1.0 & 4.2 \\
\hline $\begin{array}{l}\text { bargaining power of workers } \\
\text { and entry cost }\end{array}$ & 3.0 & 7.9 & 1.7 & 0.7 & 6.7 \\
\hline $\begin{array}{l}\text { hiring cost, bargaining power } \\
\text { of workers and entry cost }\end{array}$ & 4.8 & 9.4 & 2.6 & 1.4 & 9.4 \\
\hline
\end{tabular}

Table A6: Long-run effects of structural reform packages in South Africa. The table shows the long-run (25 years) effects of permanent and unexpected policies of size 10 percent implemented in the formal sector. 


\section{References}

Agell, J. (1999): On the benefits from rigid labour markets: norms, market failures, and social insurance. The Economic Journal, Vol. 109 (February), pp. F143-F164.

Alesina, A. - Ardagna, S. - Nicoletti, G. - Schiantarelli, F. (2005): Regulation and investment. Journal of the European Economic Association, Vol. 3, No. 4 (Jun., 2005), pp. 791-825.

Anand, R. - Khera, P. (2016): Macroeconomic Impact of Product and Labor Market Reforms on Informality and Unemployment in India. IMF Working Paper WP/16/47, March 2016.

Andres, J. - Arce, O. - Thomas, C. (2014): Structural reforms in a debt overhang. Banco de Espana Working Paper Series No. 1421, 2014.

Annett, A. - Estevao, M. - Faruqee, H. - Debrun, X. - Hallaert, J. J. (2004): Euro Area Policies Selected Issues. IMF Country Report No. 04/235.

Asturiasa, J. - Hurb, S. - Kehoec, T. J. - Ruhlf, K. J. (2016): The interaction and sequencing of policy reforms. Journal of Economic Dynamics and Control, Volume 72, November 2016, pages 45-66.

Bailey, M. - Farrell, D. - Remes, J. (2005): Domestic Services: The Hidden Key to Growth. McKinsey Global Institute.

Batini, N. - Levine. P. - Lotti, E. - Yang, B. (2011): Informality, Frictions and Monetary Policy. University of Surrey Discussion Paper 07/11, June 2011.

Behar, A. - Edwards, L. (2004): Estimating elasticities of demand and supply for South African manufactured exports using a vector error correction model. Centre for the Study of African Economies Series Working Paper 2004-04, January 2004.

Berger, H. - Danninger, S. (2005): Labor and product market deregulation: partial, sequential, or simultaneous reform? IMF Working Paper WP/05/227, December 2005.

Bernanke, B. S. - Gertler, M. - Gilchrist, S. (1999): The financial accelerator in a quantitative business cycle framework, in Handbook of Macroeconomics, edited by Taylor, J. B. and Woodford, M., Elsevier, Volume 1, 1999.

Besley, T. - Burgess, R. (2004): Can labor regulation hinder economic performance? Evidence from India. The Quarterly Journal of Economics, February 2004.

Bilbie, F. O. - Ghironi, F. - Melitz, M. J. (2012): Endogenous entry, product variety, and business cycles. Journal of Political Economy, Vol. 120, No. 2 (Apr 2012), pp. 304-345.

Blanchard, O. - Gali, J. (2010): Labor markets and Monetary Policy: A New Keynesian Model with Unemployment. American Economic Journal: Macroeconomics: Vol. 2 No. 2 (Apr 2010), pp. 1-30. 
Blanchard, O. - Giavazzi, F. (2003): Macroeconomic effects of regulation and deregulation in goods and labor markets. The Quarterly Journal of Economics, Vol. 188 (2003), Issue 3 (Aug), 879-907.

Boken, N. - Hallett, A. H. (2008): The Impact of Tax and Market Distortions on the Phillips Curve and the Natural Rate of Unemployment. Economics, Vol. 2, 2008-27, September 2008.

Boeri, T. - Garibaldi, P. (2007): Shadow sorting, in NBER International Seminar on Macroeconomics 2005, edited by Frankel, J. and Pissarides, C., National Bureau of Economic Research, May 2007.

Cacciatore, M. - Duval, R. - Fiori, G. - Ghironi, F. (2016a): Market Reforms in the Time of Inbalance. Journal of Economic Dynamics and Control 72 (2016) 69-93.

Cacciatore, M. - Duval, R. - Fiori, G. - Ghironi, F. (2016b): Short-Term Pain for Long-Term Gain: Market Deregulation and Monetary Policy in Small Open Economies. Journal of International Money and Finance, Volume 68, November 2016, pages 358-385.

Cacciatore, M. - Fiori, G. (2016): The Macroeconomic Effects of Goods and Labor Markets Deregulation. Review of Economic Dynamics, Volume 20, April 2016, pages 1-24.

Cacciatore, M. - Fiori, G. - Ghironi, F. (2016c): Market Deregulation and Optimal Monetary Policy in a Monetary Union. Journal of International Economics, Volume 99, March 2016, pages 120-137.

Carre, F. - Chen, M. A. - Heintz, J. - Hussmanns, R. - Vanek, J. (2014): Statistics on the Informal Economy: Definitions, Regional Estimates and Challenges. WIEGO Working Paper (Statistics) No 2, Women in Informal Employment Globazing and Organizing, April 2014.

Casale, D. - Muller, C. - Posel, D. (2004): 'Two Million Net New Jobs': A Reconsideration of the Rise in Employment in South Africa, 1995-2003. The South African Journal of Economics, Vol. 72:5 December 2004.

Cassim, A. - Lilenstein, K. - Oosthuizen, M. - Steenkamp, F. (2016): Informality and Inclusive Growth in Sub-Saharan Africa. Regional Evidence Paper, Evidence and Lessons from Latin America, Development Policy Research Unit, University of Cape Town South Africa, May 2016.

Charlot, O. - Malherbet, F. - Terra, C. (2015): Informality in developing economies: Regulation and fiscal policies. Journal of Economic Dynamics and Control 51 (2015) 1-27.

Christiano, L. J. - Eichenbaum, M. - Evans, C. L. (2005): Nominal Rigidities and the Dynamic Effects of a Shock to Monetary Policy. Journal of Political Economy, 2005, Vol. 113, No. 1.

Conway, P. - Janod, V. - Nicoletti, G. (2005): Product market regulation in OECD countries: 1998 to 2003. OECD Economics Department Working Papers, No. 419, OECD Publishing.

Dewatripont, M. - Roland, G. (1995): The Design of Reform Packages under Uncertainty. The American Economic Review 85(5): 1207-1223. 
Dixit, A. K. - Stiglitz, J. E. (1977): Monopolistic Competition and Optimum Product

Diversity. The American Economic Review, Vol. 67, No. 3. (Jun., 1977), pp. 297-308.

DTI (2008): Annual Review of Small Business of South Africa 2005-2007. Department of Trade and Industry, South Africa.

Ebell, M. - Haefke, C. (2006): Product Market Regulation and Endogenous Union Formation. IZA Discussion Papers 2222, Institute for the Study of Labor.

Ebell, M. - Haefke, C. (2009): Product market Deregulation and the US Unemployment Miracle. Review of Economic Dynamics 12 (2009) 479-504.

Edwards, S. (1989): On the sequencing of structural reforms. OECD Economics Department Working Papers 70, OECD Publishing.

Eggertson, G. - Ferrero, A. - Raffo, A. (2014): Can structural reforms help Europe? Journal of Monetary Economics 61 (2014) 2-22.

Estevao, M. M. (2005): Product market regulation and the benefits of wage moderation. IMF Working Paper WP/05/191, September 2005.

Farrell, D. (2004): The Hidden Dangers of the Informal Economy. McKinsey Quarterly 2004, no. 3: 26-37.

Fernandez-Villaverde, J. - Guerron-Quintana, P. A. - Rubio-Ramirez, J. (2014): Supply-side policies and the zero lower bound. IMF Economic Review (2014) 62, 248-260, July 2014.

Gali, J. (2011): The Return of The Wage Philips Curve. Journal of the European Economic Association, 9(3), 436-461.

Gerali, A. - Notarpietro, A. - Pisani, M. (2014): Macroeconomic effects of simultaneous implementation of reforms after the crisis. Bank of Italy Working Paper Number 997, November 2014.

Gomes, S. - Jacquinot, P. - Mohr, M. - Pisani, M. (2013): Structural Reforms and Macroeconomic Performance in the Euro Area Countries: A Model-Based Assessment. International Finance 16:1, 2013: pp. 23-44.

Gnocchi, S. - Lagerborg, A. - Pappa, E. (2015): Do labor market institutions matter for business cycles? Journal of Economic Dynamics and Control 51 (2015) 299-317.

Hausmann, R. - Rodrik, D. - Velasco, A. (2005): Growth Diagnostics. Manuscript, 2005.

Ihrig, J. - Moe, K. S. (2004): Lurking in the shadows: the informal sector and government policy. Journal of Development Economics 73 (2004) 541-557.

ILO (2013): Women and men in the informal economy: A statistical picture. International Labor Organisation, 2013. 
IMF (2014): South Africa Staff Report for the 2014 Article IV Consultation. International Monetary Fund, November 2014.

IMF (2015a): Structural Reforms and Macroeconomic Performance: Initial Considerations for the Fund. International Monetary Fund Staff Report, November 2015.

IMF (2015b): World Economic Outlook April 2016. Too Slow for Too Long. Chapter 3: Time for a supply-side boost? Macroeconomic effects of labor and product market reforms in advanced economies. International Monetary Fund, April 2016.

IMF (2016): Staff Background Paper for G-20 Surveillance Note. Priorities for Structural Reforms in G-20 countries. International Monetary Fund, July 2016.

IMF (2017): Sub-Saharan Africa Regional Economic Outlook April 2017. Chapter 3: The Informal Economy in Sub-Saharan. International Monetary Fund, April 2017.

Karoro, T. D. - Aziakpono, M. J. - Cattaneo, N. (2008): Exchange rate pass-through to import prices in South Africa: Is there asymmetry? Rhodes University, Working Paper Number 79, June 2008.

Khera, P. - Tulin, V. (2017): Prioritizing and Sequencing Structural Reforms and Coping with Adjustment Costs in India. Manuscript, February 2017.

Kingdon, G. G. - Knight, J. (2004): Unemployment in South Africa: the nature of the beast. World Development, Volume 32, Issue 3, March 2004, pages 391-408.

Kugler, A. - Pica, G. (2004): Effects of employment protection and product market regulations on the Italian labor market. CEPR Working Paper 4216.

La Porta, R. - Shleifer, A. (2008): The Unofficial Economy and Economic Development. Brookings Papers on Economic Activity, Fall: pp. 275-352.

Lombardo, G. - Vestin, D. (2007): Welfare Implications of Calvo vs. Rotemberg Pricing Assumptions. European Central Bank Working Paper Series, NO 770, June 2007.

Lusinyan, L. - Muir, D. (2013): Assessing the Macroeconomic Impact of Structural Reforms: The Case of Italy. IMF Working Paper 13/22, January 2013.

McKeever, M. (1998): Reproduced Inequality: Participation and Success in the South African Informal Economy. Social Forces, June 1998, 76(4): 1209-41.

Mirus, R. - Smith, R. S. (1997): Canada's Underground Economy: Measurement and Implications, in The Underground Economy: Global Evidence of its Size and Impact, edited by Lippert, O. and Walker, M., The Fraser Institute, 1997.

Mortensen, D. T. - Nagypal, E. (2007): More on unemployment and vacancy fluctuations. Review of Economic Dynamics 10 (2007) 327-347.

Murphy, K. M. - Shleifer, A. - Vishney, R. W. (1992): The Transition to a Market Economy: Pitfalls of Partial Reform. The Quarterly Journal of Economics, August 1992: 889-906. 
Nicoletti, G. - Scarpetta, S. (2003): Regulation, productivity, and growth: OECD evidence. World Bank Policy Research Working Paper 2944, January 2003.

Pappa, E. - Sajedi, R. - Vella, E. (2015): Fiscal consolidation with tax evasion and corruption. Journal of International Economics 96 (2015) S56-S75.

Rotemberg, J. J. (1982): Sticky prices in the Unites States. Journal of Political Economy, Vol. 90, No. 6 (Dec., 1982), pp. 1187-1211.

Schmitt-Grohe, S. - Uribe, M. (2003): Closing small open economy models. Journal of International Economics, Elsevier, vol. 61(1), pp. 163-185, Oct 2003.

Schneider, F. (2005): Shadow economies around the world: what do we really know? European Journal of Political Economy, Vol. 21 (2005), 598-642.

Schneider, F. (2012): The shadow economy and work in the shadow: what do we (not) know? Institute for the study of labor, IZA Discussion Paper No. 6423, March 2012.

Schneider, F. - Buehn, A. - Montenegro, C. E. (2010): New estimates for the shadow economies all over the world. International Economic Journal, 24:4, 443-461.

Schneider, F. - Enste, D. H. (2000): Shadow economies: size, causes, and consequences. Journal of Economic Literature, Vol. XXXVIII, March 2000.

Smets, F. - Wouters, R. (2007): Shocks and Frictions in US Business Cycles A Bayesian DSGE Approach. Working Paper NO 722, European Central Bank, February 2007.

SSA (2006): Survey of Employers and the Self-Employed. Statistics South Africa, November 2006.

SSA (2010): Survey of Employers and the Self-Employed. Statistics South Africa, October 2010.

SSA (2014): Survey of Employers and the Self-Employed. Statistics South Africa, August 2014.

SSA (2017): Quarterly Labour Force Survey Quarter 4: 2016. Statistics South Africa, February 2017.

Steinbach, R. - Mathuloe, P. - Smit, B. (2009): An open economy New Keynesian DSGE model of the South African economy. South African Journal of Economics, Volume 77, Issue 2, pp. 207-227, June 2009.

Vogel, L. (2014): Structural reforms at the zero lower bound. Economic Papers 537, European Commission, November 2014.

Williamson, O. E. (1975): Markets and Hierarchies, Analysis and Antitrust Implications: A Study in the Economics of Internal Organization. The Free Press, December 1975. 
Wills, G. (2009): South Africa's Informal Economy: A Statistical Profile. WIEGO Working Paper (Urban Policies) No 6, Women in Informal Employment Globazing and Organizing, April 2009. 